NBER WORKING PAPER SERIES

\title{
RESIDENT AND NONRESIDENT TUITION AND ENROLLMENT AT FLAGSHIP STATE UNIVERSITIES
}

\author{
Michael J. Rizzo \\ Ronald G. Ehrenberg \\ Working Paper 9516 \\ http://www.nber.org/papers/w9516 \\ NATIONAL BUREAU OF ECONOMIC RESEARCH \\ 1050 Massachusetts Avenue \\ Cambridge, MA 02138 \\ February 2003
}

Rizzo is a PhD candidate in economics at Cornell University and a research assistant at the Cornell Higher Education Research Institute (CHERI). Ehrenberg is the Irving M. Ives Professor of Industrial and Labor Relations and Economics at Cornell University, Director of CHERI, and a research associate at the National Bureau of Economic Research. Without implicating them for what remains, we are grateful to the Andrew W. Mellon Foundation and the Atlantic Philanthropies (USA) Inc. for their support of CHERI and to Michelle White, Caroline Hoxby and participants at the NBER conference for their comments on an earlier version. The views expressed herein are those of the author and not necessarily those of the National Bureau of Economic Research.

(C2003 by Michael J. Rizzo and Ronald Ehrenberg. All rights reserved. Short sections of text not to exceed two paragraphs, may be quoted without explicit permission provided that full credit including (Cnotice, is given to the source. 
Resident and Nonresident Tuition and Enrollment at Flagship State Universities

Michael J. Rizzo and Ronald G. Ehrenberg

NBER Working Paper No. 9516

February 2003

JEL No. I2

\begin{abstract}
We address the determinants of resident and nonresident tuition and enrollment at public universities. A key explanatory variable is the share of out-of-state students enrolled under reciprocity agreements. We find that public universities use out-of-state enrollments primarily to augment student quality, not to make up for losses in state appropriations.In the main out-of-state enrollment levels are relatively insensitive to out-of-state tuition levels charged by institutions. Finally, we find no evidence that public universities increase their in-state or out-of-state tuition levels in response to increased federal or state financial aid for students.
\end{abstract}

Michael J. Rizzo

Cornell Higher Education Research Institute

ILR-Cornell University

256 Ives Hall

Ithaca, NY 14853-3901

mjr38@cornell.edu
Ronald G. Ehrenberg

Cornell Higher Education Research Institute

ILR-Cornell University

256 Ives Hall

Ithaca, NY 14853-3901

and NBER

rge2@cornell.edu 


\section{Introduction}

The recent economic downturn in the United States has led to severe current and projected budget deficits in most states. Sharp rises in healthcare costs and increased competition for state funds from other sources has concurrently led to a decrease in the shares of state budgets earmarked for the higher education sector. ${ }^{1}$ Because universities are able to attract revenue from other sources (e.g. tuition, annual giving and federal student aid) and they are a discretionary component of most state budgets, they are often the first to go under the knife during tough times. The resulting revenue shortages from these budget cuts will most certainly have deleterious effects on college accessibility and on the behavior of these higher educational institutions. Inasmuch as $65 \%$ of the 9.2 million students enrolled in four-year institutions in 1999 were enrolled in public institutions and in most states the major public research universities are also the most selective in terms of admissions, it is important to understand institutional responses relating to tuition and enrollment policies, as well as the likely changes in state grant aid policies.

During the 1979 to 2000 period, the average state appropriation at the flagship public research institutions, as a share of total current fund revenues at the institution, fell from $42 \%$ to $31 \%$. Only ten institutions saw increases in the share of their revenues coming from state appropriations over this period, and only three of these saw any increase in the share during the 1988 to 2000 period.

\footnotetext{
${ }^{1}$ From FY92-FY02, the share of states' discretionary budgets allocated to higher education has fallen 0.8 percentage points from $13.5 \%$ to $12.7 \%$. Health care's share has risen from $12.1 \%$ to $16.0 \%$ during this time. See National Association of State Budget Officers, State Expenditure Report 2001.
} 
To make up for this revenue shortfall, public institutions are largely constrained to using two tools. ${ }^{2}$ First, they may increase the tuition they charge in-state students, however this is often a politically unpopular move. Second, because all public research institutions charge a higher tuition to out-of-state students than they do to in-state students, they can raise the tuition they charge out-of-state students and/or adjust the composition of their student body by enrolling more out-of-state students.

Adjusting the share of students that come from out-of-state is at best a short-run solution and for political reasons may be much less easily adjusted than the out-of-state student tuition level. After some point, it may be politically very difficult to further expand the share of out-of-state students, while state officials may not be concerned about charging nonresident students increasingly higher rates of tuition. The political difficulties arise because enrolling more nonresidents may preclude qualified students from one's own state from attending the flagship public university in the state. On the flip side, it would be unwise for a state to totally exclude nonresidents from its universities' corridors because other states might then retaliate against students from the state in question.

The prospects for revenue augmentation from increasing nonresident enrollments are diminished by the presence of tuition reciprocity agreements. These are either bilateral or multi-lateral agreements between schools and / or states allowing nonresident students to attend a public university at less than the normal out-of-state tuition. ${ }^{3}$ These agreements

\footnotetext{
${ }^{2}$ There are of course other sources of revenue. Total educational and general current fund revenues include tuition and fees, federal, state and local appropriations, government grants and contracts, private gifts, payouts from endowments, sales and services of educational activities and other sources. Local revenues are typically directed to community colleges while federal monies are focused on direct student support. The endowment levels at most publics are small, so increasing the payout rate is unlikely to have a large impact on annual revenues.
} 
are often program specific, have a regional focus and were created to encourage universities to achieve cost efficiencies in their program offerings.

An institution's ability to employ different tuition and enrollment strategies is dependent upon its degree of autonomy from state interests. Because elected state officials interests diverge from university administrators' and faculty members', we expect institutions in states where there is more legislative oversight in the form of a statewide coordinating board and/or fewer governing boards to find it more difficult to increase tuition and to adjust their enrollment margins. ${ }^{4}$

Some observers have expressed concern that direct student aid (both federal grant aid and state aid), which was designed to improve access, has instead given institutions the freedom to increase tuition. States' financing of higher education is increasingly being provided in the form of grant aid to students rather than in the form of appropriations to institutions. From 1979 to 2000, average (median) direct student aid as a share of total higher educational aid has increased from $3.0 \%$ to $5.8 \%$ (1.8\% to $4.8 \%)$. While the real value of the federal Basic Educational Opportunity Grant (Pell Grant) fell by $9 \%$ over this time period, access to federal subsidized loans was vastly expanded. In fact, by $1999,45.4 \%$ of students receiving financial aid did so in the form of federal loan aid.

How tuition levels, or the availability of grant or loan aid, influence access are empirical questions that we will not address in this chapter. Rather, we will analyze how tuition and enrollment strategies at institutions react to changes in federal and state

\footnotetext{
${ }^{3}$ In some cases, if the flow of students between states taking advantage of tuition reciprocity agreements is not roughly equal, the state that exported more students than it imported makes a payment to the importing state to compensate it for bearing more than its fair share of the costs. These payments go to the state treasury, however, not to the universities themselves.

${ }^{4}$ See Lowry (2001a, 2001b). Lowry also points out that states (schools) where a high percentage of university trustees are appointed by elected officials or directly elected by the voting public also have lower tuition.
} 
student need based aid and to state appropriations to public higher education institutions. The former increases student mobility by expanding their choice set, while the latter does not travel with the student.

Institutions may also choose nonresident enrollment policies to satisfy different interests. Since many flagship publics are also high quality institutions, they typically experience an excess demand for seats and can enroll nonresidents to improve academic quality or to enhance the diversity of their student bodies.

Given differing state governance structures, political climates, institutional objectives, and the like, it is not surprising to see the dramatic disparity across states in their use of nonresidents as an enrollment strategy. Figure 1 shows that many of the larger, more populous states such as Ohio, Illinois, Texas, California and New York, do not make great use of this strategy, enrolling less than $10 \%$ of their first time freshmen from out-ofstate in $1998 .{ }^{5}$ However, other states that are smaller, older and/or have a history of private provision of higher education enroll nearly half of their entering classes as nonresidents. Vermont, Delaware, Rhode Island and New Hampshire respectively enrolled $66 \%, 60 \%, 48 \%$ and $40 \%$ of their classes in 1998 in this manner.

Table 1 lists the 91 flagship public research institutions whose behavior is analyzed in our study. ${ }^{7}$ They are primarily Research I and II institutions and were chosen because

\footnotetext{
${ }^{5}$ The categories were defined using a means clustering analysis described by Everitt (1993). This is an exploratory data technique meant to find natural groups in the data. We chose to employ a partition method that breaks the observations into k-non-overlapping groups. Multiple iterations suggest that the most natural partition was 4 groups. States near the average include Maine and Georgia, enrolling about $20 \%$ each.

${ }^{6}$ Public Universities in Texas do not get to keep the extra tuition revenue they receive from enrolling outof-state students; this revenue flows into the state government coffers. As such they have no financial incentive to enroll out-of-state students.

${ }^{7}$ There are 84 schools from 43 states that were classified as Research I and II in 1994 by the Carnegie Foundation for the Advancement of Teaching. To fully exploit state variation in tuition, enrollment and
} 
they are the most selective and largest public institutions in each state and they enroll the largest shares of nonresidents, or out-of-state students. This chapter is motivated by our desire to understand the causes and consequences of nonresident enrollment. We seek to explain how the share of nonresidents among first-time freshmen varies at a point in time across these institutions and over time at any given institution. We employ panel data from a variety of sources and estimate a system of equations to explain the levels of state need-based grant aid per student, in-state tuition, out-of-state tuition and the share of outof-state students among first-time freshmen. The longitudinal nature of the data permits us to control for omitted variable bias.

In the next section, we briefly survey related literature. Section III presents information on trends in tuition, enrollment and grant aid. In addition to summarizing the data we use to explain these trends, it also discusses the results of a survey we undertook to obtain information on the nature and prevalence of tuition reciprocity agreements. Section IV describes our estimation strategy, presents empirical results and conducts some policy simulations based upon these results. Section V briefly concludes.

\section{Selective Literature Review}

The literature on pricing and access in public higher education is replete with papers that analyze issues related to one or more of state grant aid, in-state tuition, out-of-state tuition and nonresident enrollment shares, but none has studied all of these issues simultaneously. Two papers have addressed the determinants of nonresident enrollments. Mixon and Hsing (1994) found, using cross-section data for a sample of public and

grant aid policies, we added the flagship public institution from each state that did not have a Research I or II institution. These states were Alaska, Maine, Montana, Nevada, New Hampshire, North Dakota and South Dakota. 
private academic institutions, that higher nonresident tuition levels were associated with higher nonresident enrollment shares. Their findings lent credence to the notion that universities enroll nonresidents for revenue purposes. Siow (1997) found, after controlling for student body ability, that universities with more successful researchers were more likely to have larger shares of nonresident and foreign students.

Other studies have addressed the determinants of tuition levels for in-state students at public universities. Using cross-section data, Lowry (2001a, 2001b) found that net tuition and fee revenues were higher at public universities that receive less state government funding per student and in states in which public universities have more financial autonomy. Quigley and Rubinfeld (1993) found that states with high private enrollments and many private colleges and universities charged higher tuition levels at their public universities.

Several studies have treated tuition levels at public higher education institutions and state appropriations to these institutions as being simultaneously determined. In the context of a model in which state appropriations were treated as endogenous, Koshal and Koshal (2000) found that lower state appropriations per student, higher median family income and a higher share of students that came from out-of-state were all associated with higher in-state tuition levels. However, Lowry's (2001a, 2001b) work suggests that state appropriations per student can be treated as exogenous in in-state tuition equations.

Greene (1994) is one of the few studies that addressed out-of-state tuition levels at public universities. Using cross-section data, he found that states with many private colleges, lower tax rates, poor labor markets and with strong in-migration of both population and students, charged higher nonresident tuition. While he observed that 
higher regional tuition was associated with higher nonresident tuition levels, the association was not statistically significant.

Research relating to federal and state grant aid has addressed how grant aid affects tuition levels and access. Examples include Balderson (1997), Coopers and Lybrand (1997), Haupman and Krop (1998), McPherson and Shapiro (1998), and National Center for Education Statistics (2001). Of concern to many researchers and policymakers is whether academic institutions respond to increases in the Pell Grant program maximum benefit level by increasing their tuition levels. Estimates of the size of this "Bennett Hypothesis" at public institutions range from negligible to a $\$ 50$ increase in tuition for every $\$ 100$ increase in aid. ${ }^{8}$ Little attention has been given to the determination of federal grant aid levels themselves, let alone to how states determine how much of their resources to devote to financial aid for students.

Most of the prior studies are cross-section analyses, and are subject to the criticism that unobserved institutional or state specific variables may lead to biased coefficient estimates. To avoid this problem, we employ a rich longitudinal institutional level data set that is derived primarily from the Higher Educational General Information System (HEGIS) and its successor the Integrated Postsecondary Education Data System (IPEDS) in the estimation reported below. The HEGIS and IPEDS data are supplemented with data from numerous other sources.

We report estimates of a system of four simultaneously determined equations for state need-based grant aid, in-state tuition, out-of-state tuition and the share of undergraduate students that are nonresidents. The explanatory variables that are treated as exogenous in our models include federal financial aid parameters, institutional

\footnotetext{
${ }^{8}$ Named for William Bennett, the Secretary of Education during the Reagan administration.
} 
characteristics, state governance characteristics, tuition reciprocity agreement parameters, measures of higher education competition in the state and the institution's enrollment capacity, and other state and regional specific information. Our analyses should be viewed as reduced form in nature due to the difficulty of finding suitable supply and demand restrictions for each equation.

\section{Data}

Our study uses data on resident and nonresident enrollment and tuition levels for a sample of 91 American public research institutions representing all 50 states. The data come from a variety of sources including HEGIS, IPEDS, the National Association of State Student Grant and Aid Programs (NASSGAP) and annual Current Population Surveys (CPS), as well as other sources. Our econometric analyses use data for eight years during the 1979 to 1998 period. ${ }^{9}$

Table 2 presents data on the shares of full-time first-time freshmen that were nonresidents at sample institutions during the 1979 to 1998 period. Overall, the enrollment share of nonresidents rose from .174 to .191 during the period. However, from 1981 through 1992, when states faced particularly difficult financial times, the average share increased from .166 to .205 , an increase of almost .04 and then remained relatively constant as budget situations improved during the remainder of the period.

To illustrate the magnitude of a 4 percentage point increase in nonresident enrollment, consider a school with a freshmen enrollment of 3,000 students and a

\footnotetext{
${ }^{9}$ Appendix Table 1 details the sources for all of our data. The specific years included in the study were dictated by the years in which information on resident and nonresident enrollments were collected as part of HEGIS or IPEDS. The 1998 academic year is the most recent year for which IPEDS Residence and Migration data is publicly available.
} 
nonresident tuition premium of $\$ 6,000$. If this school decides to enroll $4 \%$ more of its class as nonresidents (120 students), over the course of four years, this would provide the institution with an additional $\$ 2.88$ million of revenues that could be used to raise faculty salaries, invest in start-up costs for new scientists, hire additional faculty and staff, reduce class sizes and offer more courses.

Schools that exhibited the largest increases in nonresident enrollment shares during the period included Pittsburgh, Massachusetts, Minnesota and Mississippi State, which all more than doubled their shares during the period. In contrast, Illinois-Chicago, Texas Tech, Houston, South Florida and the University of California schools reduced their nonresident enrollment shares by more than half. While the time series variation in nonresident enrollment shares exhibited in this table may not appear very striking, more dramatic cross-section variation exists and can be seen in figure 1.

The well-documented increases in resident and nonresident tuition that occurred during the period are shown in Table 3. In real terms, resident and nonresident tuition levels both more than doubled between 1979 and 1998, with each growing at about 4\% per year above the rate of inflation. This table veils the dramatic cross-section variation that exists in public higher education tuition levels. For instance, in 1998 Vermont charged its residents over $\$ 7,000$ and Pittsburgh, Temple, Michigan, Penn State, and New Hampshire all charged over $\$ 6,000$, while all of the Florida universities, Arizona universities, Idaho, Houston, Texas A\&M and Nevada-Reno charged near $\$ 2,000$. The public higher education institutions in California and Texas are among those that increased tuition at the fastest rates, while the Florida and Mississippi schools exhibited the smallest increases during the period. 
Every public research institution charges a higher price to nonresidents, presumably because state taxpayers do not want to subsidize the schooling of nontaxpayers from other states. Moreover, the extent to which nonresidents pay more than residents increased during the period. The roughly equal percentage increases during the period in resident and nonresident tuition caused the real difference in resident and nonresident tuition levels to substantially increase during the period.

Table 3 shows that while in-state tuition increased by an average of less than $\$ 2,000$ in real terms, nonresident tuition increased by an average of more than $\$ 5,000$ in real terms. As a result the average premium charged to nonresidents has increased in real terms from $\$ 2,700$ in 1979 to over $\$ 6,500$ in 1998 (table 4). The raw data suggest that during the period institutions adjusted their out-of-state tuition levels to generate revenue.

The lowest out-of-state tuition levels and smallest increases occurred largely in the southeastern region. Both the largest out-of-state tuition levels and tuition increases occurred at Michigan, the Virginia schools, North Carolina schools and the California schools. As with the overall level of nonresident tuition, the smallest premia charged to nonresidents and the smallest increases tended to occur at southeastern public institutions. The strong regional patterns that we observe in tuition and enrollment trends suggests the importance of historical competitive and political economic factors.

Turning to trends in state support for public higher education, tables 5 and 6 outline the changes in state need based grant aid to students attending public institutions and state appropriations to public higher education institutions that occurred during the period. Table 5 shows that average state provided need based grant aid per full-time equivalent undergraduate enrolled in public higher education institutions in the state has 
more than quadrupled in real terms, growing from roughly $\$ 67$ per student per year to $\$ 285$ per student per year. ${ }^{10}$ One recent study found that $68.5 \%$ of first-time, full time students enrolled in public higher educational institutions received financial aid from any source and that $26.9 \%$ of these students received state grant aid averaging $\$ 1,742$ per year. ${ }^{11}$ Inasmuch as the average in-state tuition in 1998 was $\$ 3,525$, state grant aid alone appears to cover over half of the tuition costs for eligible students.

Among the most generous states, in terms of state provided grant aid per fulltime equivalent student enrolled in public higher education institutions are New York, Illinois and Pennsylvania, while the least generous states include Wyoming, Utah, Montana and Mississippi. New Mexico, Virginia, Washington, Maine and Massachusetts are among those states that increased state aid per student the fastest during the period, while Utah, Wyoming, Montana, Alabama and Mississippi actually decreased in real terms the amount of need based grant aid they awarded per student enrolled in public institutions during the period. While direct student aid grew rapidly, real state appropriations per full-time equivalent student to public higher education institutions saw very little growth during the period. Table 6 summarizes data on real average state government appropriations per full-time equivalent undergraduate. Nationwide real state appropriations per student did not increase between 1988 and 1998, and only grew by $21 \%$ between 1979 and 2000, a 1\% per annum annual growth rate. Again, dramatic cross-section variation existed in state funding per student.

\footnotetext{
${ }^{10}$ Though the annual percentage increases in real student grant aid (7.5\%) outpaced the annual real increases in tuition $(4.5 \%)$, the real dollar cost to students still rose during the period.

${ }^{11}$ National Center for Education Statistics (2001). In addition, 28.3\% of aid recipients receive federal grants averaging $\$ 2,262,30.9 \%$ of aid recipients received institutional grants averaging $\$ 2,576$ per student and 45.4\% received loan aid averaging $\$ 3,490$ per student in 1999 .
} 
A few states were able to generously increase support for selected institutions during the period. New Mexico, Maryland, Georgia Tech, Maine and Oklahoma State all enjoyed a doubling of real state support, amounting to increases between $\$ 6,000$ and $\$ 12,000$ per student. However, of the 91 schools in our sample, 22 faced decreases in real state appropriations per student between 1979 and 2000. Among the hardest hit were many of the California and Virginia schools, each losing anywhere from $10 \%$ to $49 \%$ of its state support. These losses represented $\$ 1,000$ to $\$ 12,000$ per student cuts in real state appropriations.

In the face of budget pressures and changing political attitudes, states may have an easier time funding direct student aid increases under the guise of promoting access. Legislators and their constituents may also prefer not to fund institutions directly, because they may worry that the dollars will not go to the intended uses. Raw correlations, however, do not indicate that states that are more generous to students are less generous to institutions (the simple correlation coefficient is 0.14 ). In fact, it appears that there are states that are generous to higher education on both dimensions and states that are not.

Figure 2 depicts state preferences for direct student aid versus institutional aid in 1996, controlling for per capita tax revenues. ${ }^{12}$ The axes represent US averages. We see that New York, Michigan, Maryland and California exert a great deal of effort to fund both student financial aid and state appropriations to public higher education, while Wyoming, Nebraska, Delaware, Idaho, Utah and Montana fund neither very well. Some

\footnotetext{
${ }^{12}$ The figure plots normalized residuals from a regression of grant aid on per capita tax revenues in 1996 against residuals from a regression of state appropriations on per capita tax revenues in 1996. These are institutional level regressions and each point on the graph represents enrollment weighted state averages for those states with multiple institutions.
} 
states do appear to prefer one form of aid to another. New Jersey, Minnesota, Pennsylvania and Illinois are above average funders of public higher education institutions, while Alaska, Hawaii, North Dakota and Mississippi are above average funders of aid to students. ${ }^{13}$ Wealthier and larger states seem to support higher education on both fronts (northeast quadrant of figure) more greatly than the rural and poorer states (southwest quadrant). It is somewhat of a surprise that no clear regional disparities emerge when comparing state preferences for direct student aid versus in-kind institutional aid.

During the 1990s, Arkansas, Florida, Georgia, Mississippi and New Mexico each introduced direct student financial aid programs that were based on student performance rather than student need. In some cases these grant aid awards came at the expense of their need-based aid programs. The largest program was Georgia's HOPE scholarship program which awarded \$208M of Georgia's total grant aid support of \$209M in academic year 1998. Florida and New Mexico’s programs each comprised well over $50 \%$ of their states' total grant aid funding, while the programs in Mississippi and Arkansas were very small.

Tuition reciprocity agreements are agreements between a school or state and another state or consortium that allow a nonresident student from a neighboring state to attend the public institution at less than the normal out-of-state tuition. The magnitude of the discount may depend on the type of program in which a student is interested, the county in which a student resides, the availability of opportunities in the home state, whether the student is an undergraduate or graduate, whether the student attends part- or

\footnotetext{
${ }^{13}$ This table shows results for need based aid. Many states are now moving to merit-based aid programs (e.g. GA) and inclusion of this would alter this picture.
} 
full-time and many other factors. While some schools negotiate agreements bilaterally with other states, many now choose to participate in consortium agreements in which a number of states in a geographical region are treated similarly under the agreement.

Tuition reciprocity agreements typically do not require that an institution accept a given number of students, or all students whose "quality" is above a specified level, from out-of-state. They only specify that if the out-of-state students are admitted that the tuition charged to them be below the normal out-of-state student rate. Given that the political process has approved the agreement, at the margin, institutions will only accept students under a tuition reciprocity agreement if there is excess capacity at the institution for the programs in which the students are applying, or if the accepted students yield more in prestige to the university than accepting more in-state students would yield the institution and if rejecting the marginal in-state students will not cause political problems for the institution. ${ }^{14}$

Under these circumstances, the marginal revenue received by the public university from accepting out-of-state students enrolled under tuition reciprocity agreements is always at least equal to the marginal revenue the institution would have received if it had not enrolled these students. While the marginal revenue the institution receives from a student admitted under a tuition reciprocity agreement may be less than the institution would have received if it could have enrolled more out-of state-students paying its normal out of state tuition, the latter would not always be possible. Moreover, the state as a whole is better off with the tuition reciprocity agreement because of the

\footnotetext{
${ }^{14}$ Because of these conditions, sometimes the flagship institutions in a state opt out of the program. So for example, the University of California campuses are not part of the Western Interstate Commission on Higher Education (WICHE) undergraduate exchange consortium, but the California Maritime Academy at California State University is a participant.
} 
opportunity that students from it also have to study in other states' public institutions. As we have indicated above, if the balance of students flowing between two states is not equal, often there are additional payments made directly to the coffers of the state that is receiving more students than it is sending.

In the spring of 2001, the Cornell Higher Education Research Institute conducted a "Survey of Tuition Reciprocity Agreements at Public Research and Doctoral Universities". The sample consisted of all 149 public institutions that were classified as Research or Doctoral institutions by the Carnegie Foundation in their 1994 classification scheme. Sixty-one of the 128 universities that responded to the survey said that they participated in a tuition reciprocity program with schools in another state, or as part of a consortium. Table 7 indicates that 39 of the 91 institutions in our sample, a slightly smaller percentage than found in our reciprocity survey sample, participated in such an arrangement.

Four consortia are represented among our survey responses: the Academic Common Market, the Midwest Student Exchange Program, the New England Regional Student Program and the Western Interstate Commission for Higher Education. Some institutions in the survey also participate in student exchange programs (e.g. the National Student Exchange, the Consortium of Universities in the Washington Metropolitan Area and the Tuition Exchange, Inc.). Student exchange programs differ from reciprocity agreements in that students participating in them are either visiting another school for a specified time period, or eligibility is limited to a narrowly defined group of students. ${ }^{15}$

\footnotetext{
${ }^{15}$ A brief description of each of the consortia and exchange programs and the institutions participating in each is found at http://www.ilr.cornell.edu/cheri, click on surveys and then click on tuition reciprocity.
} 
While the number of schools participating in these agreements has not changed over our sample period, columns 4 and 5 suggest that students have been increasingly taking advantage of such programs. In addition, the schools that report reciprocal enrollments also enroll a larger share of nonresidents than the average school in our survey. In 1996 for example, an average of $23.9 \%$ of enrolled students were nonresidents in the 28 schools reporting reciprocal enrollments while an average of $19.6 \%$ of enrolled students were nonresidents in the entire sample.

Increasing nonresident enrollment shares under these programs does not translate into higher revenues for public higher education institutions given that these students often pay the in-state tuition level. ${ }^{16}$ The final column of the table indicates that for these schools, nearly a quarter of their nonresident enrollments are covered under this plan. Returning to our example from earlier, a typical school would then forego about $\$ 720,000$ in additional tuition revenues due to the presence of these agreements. ${ }^{17}$

\section{Estimation Strategy \& Results}

\section{A) Model Specification}

To achieve a fuller understanding of the causes and consequences of changing tuition and enrollments, we move to a multivariate analyses. We estimate a system of

\footnotetext{
${ }^{16}$ Recall from above that sometimes revenues flow from one state to another if the flow of students across the two states does not equalize. However, such revenues accrue to the state, not to the academic institution.

${ }^{17}$ Of course, it is unlikely that anyone would leave cash on the table. The long term cost savings from eliminating program duplication will very likely make up for the revenue losses. States might also gain politically from engaging in these agreements. States that send students likely save money because they do not have to establish and maintain costly programs. States and colleges that receive students can operate programs more efficiently because they gain quality students and if the supply of students is elastic, they might be able to fill spaces that otherwise would have been vacant. Students benefit by not having to pay out-of-state tuition, which may have prevented many of them from earning degrees in the fields they had chosen.
} 
four simultaneously determined equations using panel data, with the institution - year as our unit of analysis, in which the logarithm of state need-based grant aid per student, the logarithm of in-state tuition, the logarithm of out-of-state tuition and the logarithm of the odds-ratio of the share of first time freshmen that are nonresidents are each specified to be functions of each other, state and institutional level variables, federal financial aid variables and random uncorrelated (across equations) error terms. ${ }^{18}$ Our model should be thought of as being reduced form, rather than structural, because the variables found on the right hand side of each equation likely capture both demand and supply factors and represent an equilibrium condition in the underlying structural model.

To give the reader a sense of the sides of the market from which each variable originates and how the system of equations is identified, table 8 summarizes the variables that are excluded and included in each equation. A blank indicates that the variable is excluded from that equation. For included variables, a " $D$ " indicates that the variable is assumed to influence the outcome through the demand side of the market, an "S" that it is assumed to influence the outcome through the supply side of the market, and a "B" that it is assumed to influence the outcome through both sides of the market. Similarly, a "+" indicates that we expect that the net effect of the variable is to increase the outcome, a "-." that we expect that the net effect of the variable is to decrease the outcome and a "?" that the prediction is ambiguous.

The state need-based grant aid equation is assumed to result from the interaction of students' demand for financial aid and the state's willingness to supply it. The in-state tuition equation is assumed to result from the interaction of in-state students' demand for seats at the institution and the institution's willingness to supply such seats. The

\footnotetext{
${ }^{18}$ The first variable, average state need-based aid per student is observed at the state, not institutional level.
} 
institution's willingness to supply seats can be thought of as being derived from a utility maximizing model of university behavior in which the objective of the university is to maximize its prestige, which in turn depends upon the average quality of the students that it enrolls, subject to a balanced budget constraint (Ehrenberg and Sherman 1984, Ehrenberg 2000, Garvin 1980, Winston 1999). A public university's behavior may also be constrained by its state government, which may have different objectives than the university does. For example, while the university may want to maximize student quality, the political process may want to keep in-state tuition as low as possible (Groen and White 2001). The out-of-state tuition and the share of nonresident students enrolled at an institution are similarly assumed to result from the interaction of out-of-state students' demand for seats at the institution and the institution's willingness to supply such seats, the latter constrained by the political process in the state.

The grant aid equation includes variables that relate to federal, other state and institutional sources of student financial aid. Federal loan and grant program variables included in the model are the size of the maximum Pell grant (PELL), the share of households with incomes below that necessary to be eligible for a Pell (ELIG), the percent cap on costs (CAP) and categorical variables that indicate the degree the degree of access that students have to subsidized federal loans(1979, 1992). ${ }^{19}$ The presence of state merit aid programs (MERIT) would both reduce student demand for need based aid and reduce a state's pool of available resources from which it might fund need-based aid

\footnotetext{
${ }^{19}$ The percent cap is a percentage of college costs that students were eligible to receive in Pell grants. The cap was removed in 1992, so that students at low-tuition institutions that were eligible for the maximum Pell grant could use any funds in excess of tuition costs to pay for living and other expenses. In 1981, student access to subsidized loans was dramatically reduced with the repeal of the Middle Income Student Assistance Act (MISAA) after a run-up in usage from its inception in 1978. Access was expanded again in 1992 with the removal of a portion of housing assets in the expected family contribution formula.
} 
programs. Variables that relate to institutional sources of aid are the logarithm of real state appropriations per student (APP), the logarithm of real endowment per student (END) and the logarithm of in-state tuition (TUITI) - each of these variables generates income that the institution can use, in principle, for scholarship aid. Also included in this equation to help capture a state's financial capacity to provide need based student aid are its real tax revenues per capita (TAX), its unemployment rate (UNEMP) and the share of its population that is college aged (AGE).

To control for the impact of enrollment pressure on grant aid, we include a measure of state seating capacity (SEAT), calculated as the ratio of a state's predicted enrollment in its public higher education institutions to its actual enrollment in these institutions in a year. ${ }^{20}$ Additional measures of enrollment pressures that are included are the share of new students enrolled in private colleges (PRIV) and in two-year colleges (TWO). Also included in the equation are the overall quality, as measured by the Barron's rating of public (BPUB) and private (BPRIV) institutions in the state, the logarithm of real average tuition in the region (TUITR - excluding the state in which the institution is located) and the degree of political autonomy of each school, as measured by the number of governing boards in the state $(\mathrm{GOV}){ }^{21}$ Finally, we include the ratio of graduate enrollments to undergraduate enrollments at the institution (GRAD). ${ }^{22}$

\footnotetext{
${ }^{20}$ Predicted enrollments are calculated by dividing a state's full-time equivalent public 4 year enrollment in 1970 by the size of the college age population in the state in 1970 (ages 18-24) and then multiplying this ratio by a weighted cohort size in each year of our study. If both the share of students going to publics and college enrollment rates in a state remained constant over time, then the weight used to calculate predicted enrollments in year $t$ would simply be the size of the college age population in year $t$. Between 1970-1998, the share of students attending publics was stable (between 75-80\%), but enrollment rates increased nationwide from $28.8 \%$ to $42 \%$. To account for the enrollment rate expansion, we allow the population weight to grow as the enrollment rate grows in each year. We would prefer to have used the ratio of seats available in public colleges to the number of its high school graduates as a capacity measure, but did not do so because of endogeneity concerns.
} 
Our in-state tuition equation is similarly specified. However, real state tax revenues per capita are excluded from this equation because the impact of state resources on tuition is captured by the inclusion of real state appropriations per student (APP). The latter is treated as exogenous in our model. ${ }^{23}$ In addition, we include institutional measures of school quality - categorical variables that indicate the Barron's rank of each institution. ${ }^{24}$ More generous federal financial aid programs make it easier for a school to increase tuition for at least two reasons. First, federal financial aid may reduce barriers to entry for students at the margin of attending college. Second, institutions can increase tuition and for those students not at the grant or loan limits, each dollar of tuition increase will be covered by an additional dollar of aid, up until some maximum. The availability of merit aid will increase the desirability of attending college for all students, putting upward pressure on tuition. Increased state appropriations per student may allow schools to keep tuition low, but this increase in in-kind student aid may result in an increase in demand, forcing tuition upward. Larger endowments per student and higher Barron's rankings reflect higher institutional quality and permit higher tuition levels.

\footnotetext{
${ }^{21}$ Lowry (2001a, 2001a) hypothesized that the greater the number of different independent governing boards in a state, the more decentralized state governance of higher education was and thus the less that political pressure from the state could be used to keep tuition levels down. He found evidence that this relationship held. It is not clear, however, whether state aid per student will be higher or lower in states with more political autonomy for their higher education institutions.

${ }^{22}$ The grant aid per student equation is estimated using state level data. As such all institutional level variables, including real state appropriations per student, are excluded from this equation.

${ }^{23}$ As noted above, Lowry (2001a, 2001a) found that it was permissible to treat state appropriations per student as exogenous in the in-state tuition equation.

${ }^{24}$ For roughly three decades, Barron's Profiles of American Colleges has assigned categorical rankings to 4 -year institutions according to a subjective measure of quality. From best to worst, they rank institutions as most competitive, highly competitive, very competitive, competitive, less competitive and noncompetitive. We created a categorical variable HIGHB for those institutions in the top two categories as well as LOWB for those in the bottom two. The coefficients on these variables are then relative to the omitted middle categories.
} 
The logarithm of real out-of-state tuition (TUITO) is specified to be a function of the logarithm of real in-state tuition (TUITO) and most of the variables included in the in-state tuition equation. Again real state tax revenue per capita is excluded from the equation. A notable difference is that we replace the institution's Barron's rankings with measures of the shares of students in the state enrolled at other public (BSPUB) or private (BSPRIV) institutions in the state that are enrolled at schools of equal or better Barron's rankings than the institution. These variables capture the institution's monopoly power within the state for students seeking to attend institutions of its quality or higher. Similarly, we include the share of students in the region enrolled in schools of equal or better quality that are enrolled in private schools (SPRIV); the greater this share is the higher the average tuition will be at institutions perceived as good alternatives to the institution.

The logarithm of the share of first time freshmen that are nonresidents (NON) is included to capture the financial benefits to the institution from increasing out-of-state enrollments. Finally, we include the logarithm of the share of undergraduates that are enrolled under reciprocity agreements (RECIP).

The final equation is the nonresident enrollment share equation. The dependent variable in this equation is specified as the logarithm of the odds-ratio of the share of first time freshmen that are nonresidents to allow the error term to be normally distributed. This equation is specified very similarly to the out-of-state tuition equation, but now the logarithm of real out-of-state tuition (TUITO) is included as an explanatory variable. We also include the logarithm of the mean SAT scores in the state in which the institution is 
located (SAT) to see if states with a low supply of high "quality" high school graduates seek to recruit out-of-state students to attract top talent. ${ }^{25}$

Starting with the Georgia HOPE program, which was established in 1993, a number of states have recently adopted merit based grant aid programs for students who attend college within state. These programs increase the incentive that students from those states have to attend college within state. ${ }^{26}$ During our sample period, only Georgia, Arkansas, Florida, New Mexico and Mississippi instituted such programs (between 1994 and 1998), but seven more did so by 2002. Such programs should serve to increase the demand for in-state students to attend public institutions in the state, which may limit the public institution's ability to expand, or even maintain, its nonresident enrollment share. We include year/state interaction terms for those years in which an institution was in a state that had adopted one of these programs in the nonresident enrollment share equation to test if these programs do in fact reduce nonresident enrollment shares. ${ }^{27}$

We present two types of estimates for each equation. First, to understand why tuition, grant aid and nonresident enrollment vary across states and institutions at a point in time, we present pooled cross-section time-series estimates, using institutional level data for 8 years between 1979 and 1998. Year dichotomous variables are included in these models to control for idiosyncratic time effects.

While the wide variation in the cross-section data makes this approach appealing, it is subject to possible omitted variables bias. For example, institutions

\footnotetext{
${ }^{25}$ Groen and White (2001) discuss this issue in detail.

${ }^{26}$ Dynarski -this volume

${ }^{27}$ For example, we include a dummy variable that takes on the value of 1 for Georgia institutions in our sample for 1994, 1996 and 1998, and is zero otherwise.
} 
located in beautiful areas, other factors held constant, may be able to charge higher tuitions. In this example, omission of "beauty" as an explanatory variable might bias the estimates of other explanatory variables' parameters effects on tuition if these variables are correlated with "beauty." We have attempted to minimize this problem by including a carefully constructed, rich set of explanatory variables in our models.

An alternative way of controlling for omitted variables is to take advantage of the panel nature of the data and employ a fixed effects estimation strategy. The panel data results are useful in understanding how changes in explanatory variables affect changes in the dependent variables. In addition, the panel data results will be employed to simulate how changes in key explanatory variables will affect changes in the outcomes of interest to us.

For each approach, we estimate a jointly determined system of four equations, using a two-stage least squares (2SLS) estimation procedure to control for the endogeneity of all four outcomes. ${ }^{28}$ 2SLS estimation is necessary to attempt to correct for the biases that result from the violation of the orthogonality conditions necessary for OLS to be unbiased, though the signs of the potential biases here are ambiguous. The success of this procedure is highly dependent on finding appropriate "instruments" for the endogenous variables in the system. ${ }^{29}$

\footnotetext{
${ }^{28}$ The efficiency of a system such as ours can be improved if one accounts for the correlation among the error terms in each equation. 3SLS estimates were largely similar to the 2SLS estimates, but are not reported here due to concern that one or more of the equations in the system are misspecified, which can effect estimates in other equations (Johnston and DiNardo).

${ }^{29}$ In the grant aid equation, we instrument for in-state tuition using the institution's Barron's ranking because the quality of an institution's students likely affects tuition, but not a state's willingness to disperse financial aid to all students in the state. In the in-state tuition equation, we instrument for grant aid with state tax revenues per capita and the weighted ranking of public schools in the state. In the out-of-state tuition equation, we instrument for in-state tuition with state private enrollment share, state two year enrollment share, weighted ranking of private schools in the state, state tax revenues per capita and weighted rank of public schools in the state. Nonresident enrollment shares are instrumented with average
} 
Though finding suitable exclusion restrictions is a challenging endeavor for this system of equations, the estimates that follow in table 9 have proven to be robust to a variety of specification changes. The key exclusion restrictions that are necessary to identify the model are real state tax revenue per capita in the in state and out-of-state tuition equations and average SAT scores of high school students in the state in the nonresident enrollment share equation. Many of the other exclusions are made to reduce multicollinearity.

Estimates in a non-instrumented setting, or using different instrument sets, or from a reduced form system are all strikingly similar to the 2SLS results that follow and as such, we present only the 2SLS results. We suspect that the insensitivity of the 2SLS estimates and their similarity to OLS estimates is due to the instruments being either "too weak" or "too strong". By the former, we mean that there is not enough exogenous variation to produce a change in the outcome in question (with a corresponding large asymptotic variance matrix of the 2SLS estimator). By the latter, we mean that the instruments may also be correlated with the underlying model's disturbance term.

\section{B) Econometric Estimates: Cross - Section Findings}

The odd numbered columns of table 9 present the estimated coefficients and standard errors from the cross-section equations. Turning first to the average state needbased grant aid per student equation (column (i)), states that charge a higher level of tuition to its own residents (TUITI) also award them with more need based grant aid.

SAT scores of high school seniors in the state. In the nonresident enrollment share equation, out-of-state tuition is instrumented with state private enrollment share, state two-year enrollment share, weighted ranking of private schools in the state, state tax revenues per capita and weighted rank of public schools in the state. 
However, the average (excluding in-state) tuition in the region (TUITR) that the state is located in does not seem to affect the level of grant aid that is awarded, other variables held constant. ${ }^{30}$ Wealthier states, as measured by per capita tax revenues (TAX), award more grant aid per student, but states in which a larger share of the population is of college-aged (AGE) award less aid per student.

One might expect that growing state affinities for non-need based aid programs would crowd out spending on need based grant aid to students. The preliminary evidence varies by state. While it is not surpising to see that Georgia, Mississippi and Florida have coupled increasing merit based aid generosity with decreasing need based aid support, it is surprising to see that Arkansas and New Mexico have responded by increasing their need based aid generosity, ceteris parabis.

As expected, states with higher quality public (BPUB) and private (BPRIV) academic institutions, and thus likely higher costs, offer more grant aid. States in which a larger share of students attend low-cost (and thus likely low state-appropriations) twoyear colleges (TWO) award more grant aid per student. However, as expected, the state appropriation per student to the specific 4-year institution (APP) does not affect the average need based state aid per student attending public institutions in the state. States with greater available seating capacity in their public institutions - i.e. their predicted enrollments exceed what they actually enroll in a given year (SEAT) award less grant aid per student, contrary to our a prior expectation. Finally, institutional autonomy (GOV) does not seem to be correlated with state grant aid generosity.

\footnotetext{
${ }^{30}$ All of the results discussed in the paper are ceteris paribus, or other variables in the model held constant, findings.
} 
Moving to the in-state tuition equation (column (iii)), we find that every $10 \%$ increase in state need based grant aid per student (AID) across states is associated with public universities charging tuitions about $2.7 \%$ higher. Evidence on the impact of merit aid programs is again mixed - with Georgia and Mississippi charging higher tuition than would otherwise be expected and New Mexico charging less. Schools that receive higher state appropriations per student (APP) charge lower tuition, though the elasticity is far from unity. As expected, higher quality schools, as measured by better Barron's rankings (HIGHB) and higher endowment per student (END) are able to charge more for their product.

Turning to other variables, public universities in states in which the unemployment rate (UNEMP) is high and hence the opportunity cost of enrolling in school is low, charge higher in-state tuition, as do institutions in states in which a smaller share of students attend two-year colleges (TWO). Unlike Lowry (2001b), we find no evidence that public universities in states with more autonomous governance structures (GOV) charge higher tuition. Finally, when private competition in a state is important, as measured by the share of first time freshmen in the state that are enrolled in private academic institutions (PRIV), public universities are able to charge higher tuition.

Column (v) in part B of the table displays the results for the nonresident tuition equation. In-state tuition (TUITI) is a strong predictor of out-of-state tuition, although the elasticity is less than one. An institution's out-of-state tuition does not appear to be significantly positively associated with its nonresident enrollment share (NON). Institutions in states in which a larger share of households are eligible for Pell grants (ELIG) appear to charge lower nonresident tuition. As with in-state tuition, institutions 
with more selective Barron's rankings (HIGHB) are able to charge higher out-of-state tuition, while institutions receiving higher state appropriations per student (APP) charge less (not statistically significant). Regional competition clearly also matters, as schools located in regions in which a large share of students attend private schools (SPRIV) are able to charge more to out-of-state residents. Similarly, when the average tuition in the geographical region is higher (TUITR), schools also charge more to nonresidents. Unlike in the instate tuition equation, evidence of the impact of merit aid programs (MERIT) on tuition is not mixed - they seem to have had little effect on nonresident tuition levels.

A striking finding is that non-resident undergraduates may be partially subsidizing the huge costs of graduate education at these research universities. Across institutions, the higher is the ratio of graduate to undergraduate students (GRAD), the higher is the out-of-state undergraduate tuition. However, this finding might merely reflect that universities with larger shares of their students enrolled as graduate students may be higher quality institutions, which attract better faculty and thus can charge higher tuition levels to non-residents.

Column (vii) presents the nonresident enrollment share equation. As one might expect, institutions with higher out-of-state tuition levels (TUITO), ceteris parabis, enroll smaller shares of nonresidents. While the variables relating to federal financial aid policies do not contribute to explaining the cross-sectional variation in nonresident enrollment shares, measures relating to institutional quality and financial resources clearly do. Schools with larger endowments per student attract more nonresidents, while schools with below average Barron's rankings (LOWB) attract fewer. 
Another variable relating to institutional quality is the institution's share of enrollments in a state at schools of equal or higher quality. Other variables held constant, institutions whose enrollment is large relative to the total of all public enrollments (BPUB) or all private enrollments (BPRIV) at institutions of equal or greater quality in the state have larger shares of nonresident enrollments. ${ }^{31}$

Flagship public institutions face political pressure to ensure access to the children of state residents. We do not find however that when seating capacity at all public institutions in a state is low (SEAT), that public institutions enroll smaller fractions of nonresidents. ${ }^{32}$

We do find that schools located in states where high school student quality is relatively poor (SAT) enroll a larger share of nonresidents - they need to look elsewhere to find high quality students. Contrary to our expectations, we find that once we control for other factors, schools in states with more governing boards (GOV), hence more autonomous institutions, enroll smaller shares of nonresidents. We see that states providing higher state appropriations per student (APP) tend to enroll fewer nonresidents. While one might expect nonresidents to prefer to attend institutions that receive more state support per student, sometimes state support per student is endogenous in the sense that institutions may receive greater state appropriations per student for each in-state student they enroll. Finally, we do see some evidence that in-state residents formerly

\footnotetext{
${ }^{31}$ For example, for the public schools, we simply take the ratio of full-time equivalent first time freshmen enrollments in the school under observation and divide it by the total number of full-time equivalent first time freshmen students in public institutions in the state that have at least as high a Barron's ranking as the school under observation.

${ }^{32}$ Due to concerns that the enrollment constraints at the University of California may be heavily influencing our results, we reestimated all of our equations without these schools. These results were very similar (with larger standard errors) to those presented in the text.
} 
attending college out-of-state have been lured back home due to the availability of nonneed based aid.

\section{C) Econometric Estimates - Panel Data Results}

The even numbered columns of Table 9 present our fixed effects estimates. Because these parameters are estimated from within institution changes over time, they are useful for understanding the potential impacts of policy changes. As most of the variation in our data occurs across institutions, fewer statistically significant coefficients arise. Our discussion focuses on results that significantly differ from those found in the cross section.

Turning first to the state need based grant aid equation (column (ii)), grant aid per student does not respond to changes in either in-instate tuition (TUITI) or changes in regional tuition (TUITR) levels. Grant aid does increase when per capita state tax revenue (TAX) increases and state grant aid also responds to changes in income distribution of a state's population. An increase in the share of households whose incomes fall below the maximum level that permits them to be eligible for Pell grants (ELIG), leads to higher levels of state needs based grant aid per student.

Turning next to the in-state tuition equation (column (iv)), the panel estimates are very different from the cross-section ones. While changes in state grant aid levels (AID) now do not appear to influence in-state tuition levels, institutions are seen to respond to increases in the average tuition in their geographical region (TUITR), though the effect is small. While increased state appropriations per student (AID) are associated with lower in-state tuition changes, neither increases in endowment per student (END) nor changes in the share of students that are graduate students (GRAD) are statistically significantly 
associated with changes in in-state tuition in the panel. In addition, it does not appear that institutions are capturing the additional revenues that have been generated by federal and state financial aid programs. Neither increases in the generosity of the Pell grant (PELL) nor implementation of the merit aid programs has led to significant increases in instate tuition levels.

The nonresident tuition equation results (column (vi)) indicate that changes in instate tuition levels have an even larger effect on changes to nonresident tuition levels than the cross-section indicated. Due to the overwhelming dependence of nonresident tuition on in-state tuition, very little variation can be explained by other variables in our model. However, there are a few interesting observations to be made. While we found that schools with a higher proportion of their student body represented by graduate students (GRAD) charged higher nonresident tuition, we do not find that increases in this share are associated with increases in nonresident tuition levels. Further, there is no indication that seating capacity affects the nonresident pricing decisions of institutions.

Finally, turning to the nonresident enrollment share equations (column (viii)), while the nonresident enrollment share is not responsive to changes in out-of-state tuition levels (TUITO), it is positively related to increases in regional tuition levels (TUITR). As seats at quality private schools in the region continue to make up a larger share of overall enrollments (SPRIV), we see that nonresident enrollment shares will fall at the publics. Last, the presence of merit aid programs in Florida and Georgia have led institutions in each state to enroll far fewer nonresidents than they had before these programs were instituted. 


\section{Policy Simulations}

Table 10 outlines the effects that selected policy changes have on the four outcomes, using the panel data estimates presented in Table $9 .^{33}$ Inspection of the grant aid results indicates that changes in grant aid are primarily a result of political and demographic factors in a state, not the result of economic factors. If a state at the average per student grant aid level experienced an increase of $\$ 1,000$ in per capita tax revenues, that state would only increase per student grant aid by $\$ 11$ over an average of $\$ 307$.

Increases in state support for higher education institutions helps to curb in-state tuition increases but the magnitude of this effect is quite small. For the average institution in our sample, it would take an increase of $\$ 1,000$ in state appropriations per student to generate an in-state tuition reduction of $\$ 104$. The comparable reduction in out-of-state tuition would be only $\$ 2$.

While the elasticity of out-of-state tuition with respect to in-state tuition is close to one, the coefficient estimates imply that every $\$ 1,000$ increase in in-state tuition, leads to a larger increase, at the mean $\$ 2,584$, in out-of-state tuition. When institutions maintain the ratio of out-of state to in-state tuition, an increase in the latter is associated with a larger real increase in the former.

Finally, our estimates suggest that changes in most of the variables in the model fail to influence the share of nonresidents that public universities enroll. Even the statistical impact of reciprocity agreements is inconsequential. While increases in average tuition rates in the region tend to increase nonresident enrollment shares, clearly individual institutions have little or no control over these rates.

\footnotetext{
${ }^{33}$ The table reports marginal effects from the presented regressions evaluated at the sample means in the data. When we calculated the marginal effects for individual institutions and then took their means, the impacts were nearly identical.
} 


\section{Conclusion}

In this chapter, we have analyzed why state need based grant aid per student, instate and out-of-state tuition levels and nonresident enrollment shares differ across flagship public research universities at a point in time and how each changes over time. There are wide disparities across states in political persuasion, demographic characteristics, income, the availability of private college alternatives, historical factors, university governance and funding priorities that lead to most of the cross-section differences that we observe in these outcomes. Exploiting the panel nature of the data enables us to control for unmeasured institutional heterogeneity, but it also removes much of the variation in our data. Despite this, there are four insights to be drawn from our empirical work.

First, aside from the higher quality institutions, public universities cannot (or do not) use nonresident enrollment as a revenue generating strategy. Rather the institutions use nonresident enrollments to augment academic quality and/or to take advantage of cost efficiencies achieved through participation in tuition reciprocity agreements. The increased usage of tuition reciprocity programs suggests that institutions realize this revenue limitation. These agreements also reflect the growing regionalization of these state schools. In fact, institutions respond to higher regional tuition by charging high instate and out-of-state tuition and we see that nonresident students tend to migrate more often when average tuition in their region of residence is higher.

Second, it does not appear that institutions attempt to capture additional revenues by cannibalizing the monies provided by federal and state grant aid programs. We find no evidence that increases in the generosity of the federal Pell grant program and state 
need-based grant aid awards lead to increases in either in-state or out-of-state tuition levels. Further, there is little evidence that institutions in states where merit based aid programs were initiated have made attempts to capture these additional monies as well.

Third, it does not appear that public institutions make up for losses in state institutional appropriations by adjusting the proportion of students they enroll from out of state.

Finally, quality plays an important role in public higher education. An institution's quality, as measured by it's Barron's ranking, influences the in-state and outof-state tuition levels that it can charge and the share of its undergraduates that come from out-of-state. In total, our estimates provide some small support for the theory that institutions enroll nonresidents to enhance the quality of their student bodies.

We must caution that the period our data span ends before the recession of the early years of the $21^{\text {st }}$ century, the accompanying growing tightness in state government budgets and thus the decline in the growth, and in some cases the decline in the level, of real state appropriations per student to public higher education institutions. Finding other sources of revenue became increasingly important to public higher education institutions and a number increased their in state tuition levels at double digit rates for the 2002-2003 academic year. Time will tell if they will increasingly turn to out-of state students' tuition revenues to fill the holes in their budgets. 


\section{References}

Balderston, Frederick. "Tuition and Financial Aid in Higher Education," Economics of Education Review v16, n3 (June 1997): 337-343.

Bezmen, Trisha and Craig A. Depken II. "School Characteristics and the Demand for College," Economics of Education Review v17, n2 (April 1998): 205-210.

Brewer, Dominic J., Eric Eide and Ronald G. Ehrenberg. "Does it Pay to Attend an Elite Private College? Cross Cohort Evidence on the Effects of College Type on Earnings, Journal of Human Resources v34, (1999): 104-123.

Clotfelter, Charles T., Ronald G. Ehrenberg, Malcolm Getz and John J. Siegfried. Economic Challenges in Higher Education, Chicago: The University of Chicago Press, 1991 (NBER).

Coopers \& Lybrand, L.L.P. "The Impact of Federal Student Assistance on College Tuition Levels," Washington, DC, (September 1997).

Dynarski, Susan. "The Consequences of Merit Aid," in College Choices: The Economics of Which College, When College, and How to Pay For It, Cambridge, MA: The University of Chicago Press, 2003.

Dynarski, Susan. "Loans, Liquidity and Schooling Decisions," unpublished manuscript, Harvard University, (July 2001).

Ehrenberg, Ronald G. Tuition Rising: Why College Costs So Much, Cambridge MA: Harvard University Press, 2000.

Ehrenberg, Ronald G. and Daniel R. Sherman, "Optimal Financial Aid Policies for a Selective University”, Journal of Human Resources 19 (Spring 1984): 202-230.

Everitt, B.S. Cluster Analysis, 3rd edition. London: Edward Arnold (1993).

Garvin, David The Economics of University Behavior, New York NY: Academic Press, 1980)

Greene, Kenneth V. "The Public Choice of Non-resident College Tuition Levels," Public Choice v78, n3-4 (March 1994): 231-240.

Groen, Jeff and Michelle J. White. "In-State versus Out-of-State Students: The Divergence of Interest between Public Universities and State Governments," presented at 2001 Annual Cornell Higher Education Research Institute Conference. 
Hauptman, Arthur M. and Cathy Krop. "Federal Student Aid and the Growth in College Costs and Tuition: Examining the Relationship," In Commission on the Cost of Higher Education, Straight Talk About College Costs and Prices, Phoenix, AZ: Oryx Press (1998).

Hoxby, Caroline M. "How the Changing Market Structure of U.S. Higher Education Explains College Tuition,” NBER Working Paper No. 6323, (December 1997).

Johnston, J. and J. DiNardo. Econometric Methods, $4^{\text {th }}$ ed. NY: McGraw-Hill, 1997.

Koshal, Rajindar K. and Manjulika Koshal. "State Appropriation and Higher Education Tuition: What is the Relationship?" Education Economics v8, n1 (April 2000): 81-89.

Lowry, Robert C. "The Effects of State Political Interests and Campus Outputs on Public University Revenues," Economics of Education Review v20, (2001): 105-119 (2001a).

Lowry, Robert C. "Governmental Structure, Trustee Selection and Public Universities and Spending: Multiple Means to Similar Ends," American Journal of Political Science v45 (October 2001): 845-861 (2001b).

McPherson, Michael and Morton Owen Shapiro. The Student Aid Game: Meeting Need and Rewarding Talent in American Higher Education. Princeton, NJ: Princeton University Press (1998).

McPherson, Michael and Morton Owen Shapiro. Keeping College Affordable: Government and Educational Opportunity. Wash., DC: The Brookings Institution (1991).

Mixon, Franklin G., Jr. "A Public Choice Note on College Student Migration," International Journal of Manpower v13, n3 (1992): 63-68.

Mixon, Franklin G., Jr. and Yu Hsing. "The Determinants of Out-of-State Enrollments in Higher Education: A Tobit Analysis," Economics of Education Review v13, n4 (December 1994): 329-335.

National Center for Education Statistics. "Study of College Costs and Prices, 1988-89 to1997-98," commissioned by Congress in 1998 in the amendments to the Higher Education Act, (December 2001).

Peltzman, Sam. "The Effect of Government Subsidies-in-Kind on Private Expenditures: The Case of Higher Education," Journal of Political Economy v81, n1 (1973): 1-27.

Quigley, John M. and Daniel L. Rubinfeld. "Public Choices in Public Higher Education," in Eds. Charles T. Clotfelter and Michael Rothschild, Studies of Supply and Demand in Higher Education, National Bureau of Economic Research (1993): 243-283. 
Rose, David C. and Robert L. Sorensen. "High Tuition, Financial Aid, and Crosssubsidization: Do Needy Students Really Benefit?" Southern Economic Journal v59, n1 (July 1992): 66-76.

Siow, Aloysius. "Some Evidence on the Signaling Role of Research in Academia," Economics Letters v54, n3 (July 1997): 271-276.

Strathman, James G. "Migration, Benefit Spillovers and State Support of Higher Education," Urban Studies v31, n6 (June 1994): 913-920.

Winston, Gordon, "Subsidies, Hierarchies and Peers: The Awkward Economics of Higher Education”, Journal of Economic Perspectives 13 (Winter 1999): 13-36. 
Figure 1

1998 Average Share of First Time Freshmen that are Nonresidents at Research Institutions in the $\mathbf{5 0}$ United States

(categories computed through means clustering analysis)

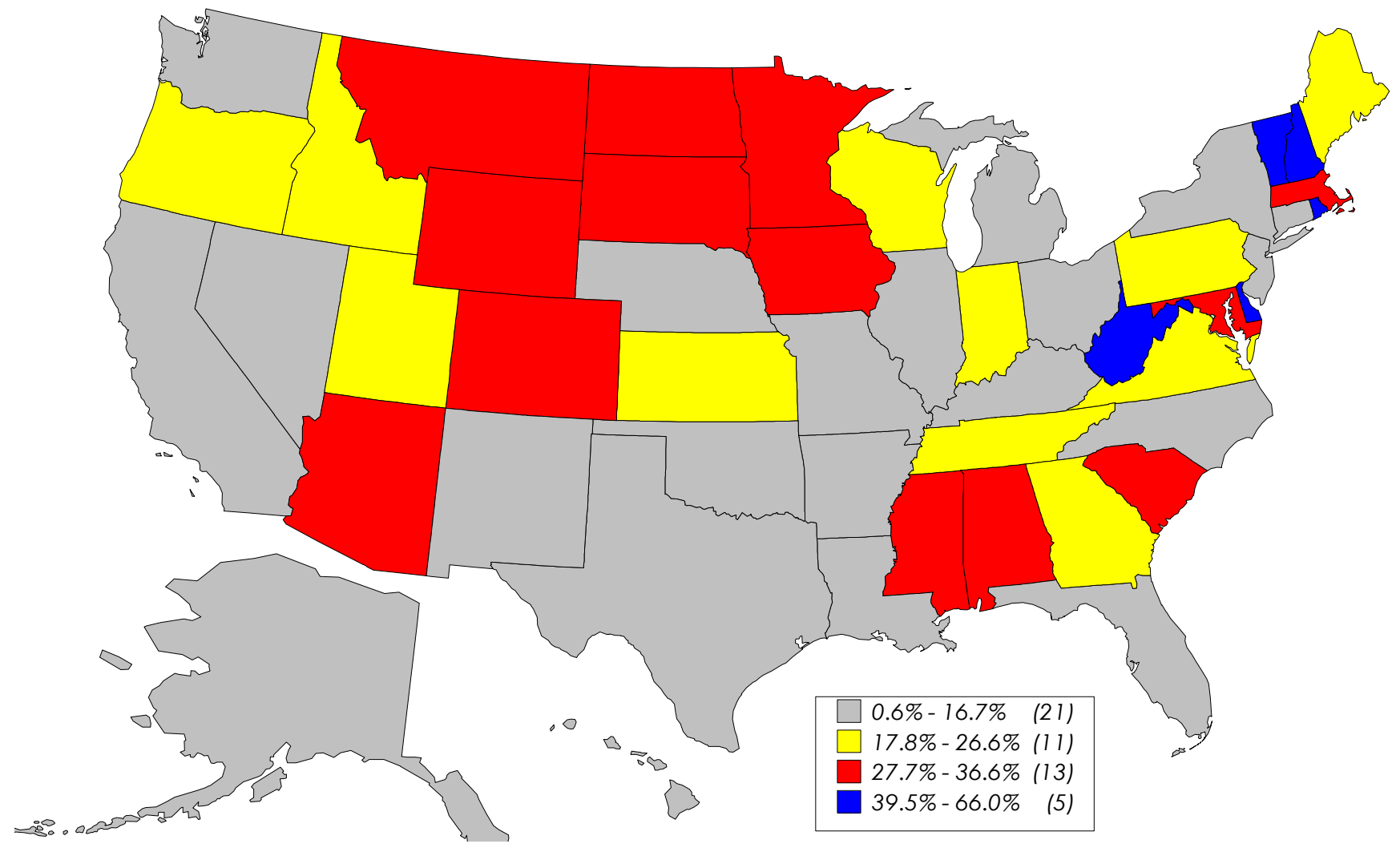


Table 1

Flagship Public Research Institutions in the Sample

\begin{tabular}{|c|c|c|c|}
\hline School & $\begin{array}{r}1994 \\
\text { Carnegie } \\
\text { Classification }\end{array}$ & School & $\begin{array}{r}1994 \\
\text { Carnegie } \\
\text { Classification }\end{array}$ \\
\hline Arizona State University (AZ) & RI & University of Hawaii at Manoa (HI) & $\overline{\mathrm{RI}}$ \\
\hline Auburn University $(A L)$ & RII & University of Houston (TX) & RII \\
\hline Clemson University (SC) & RII & University of Idaho (ID) & RII \\
\hline Colorado State University (CO) & $\mathrm{RI}$ & University of Illinois at Chicago (IL) & RI \\
\hline Florida State University (FL) & $\mathrm{RI}$ & University of Illinois at Urb.-Champaign (IL) & RI \\
\hline Georgia Institute of Technology (GA) & $\mathrm{RI}$ & University of lowa (IA) & RI \\
\hline Indiana University at Bloomington (IN) & $\mathrm{RI}$ & University of Kansas (KS) & $\mathrm{RI}$ \\
\hline Iowa State University (IA) & $\mathrm{RI}$ & University of Kentucky (KY) & $\mathrm{RI}$ \\
\hline Kansas State University (KS) & RII & University of Louisville (KY) & RII \\
\hline Kent State University $(\mathrm{OH})$ & RII & University of Maine (ME) & DIl \\
\hline Louisiana State University (LA) & $\mathrm{RI}$ & University of Maryland - College Park (MD) & RI \\
\hline Michigan State University (MI) & $\mathrm{RI}$ & University of Massachusetts - Amherst (MA) & RI \\
\hline Mississippi State University (MS) & RII & University of Michigan (MI) & $\mathrm{RI}$ \\
\hline New Mexico State University (NM) & $\mathrm{RI}$ & University of Minnesota - Twin Cities (MN) & RI \\
\hline North Carolina State University (NC) & $\mathrm{RI}$ & University of Mississippi (MS) & RII \\
\hline Ohio State University $(\mathrm{OH})$ & $\mathrm{RI}$ & University of Missouri, Columbia (MO) & $\mathrm{RI}$ \\
\hline Ohio University $(\mathrm{OH})$ & RII & University of Montana (MT) & DII \\
\hline Oklahoma State University (OK) & RII & University of Nebraska at Lincoln (NE) & RI \\
\hline Oregon State University (OR) & $\mathrm{RI}$ & University of Nevada-Reno (NV) & DII \\
\hline Pennsylvania State University (PA) & $\mathrm{RI}$ & University of New Hampshire (NH) & DII \\
\hline Purdue University (IN) & RI & University of New Mexico (NM) & $\mathrm{RI}$ \\
\hline Rutgers University - New Brunswick (NJ) & $\mathrm{RI}$ & University of North Carolina - Chapel Hill (NC) & $\mathrm{RI}$ \\
\hline Southern Illinois Univ-Carbondale (IL) & RII & University of North Dakota (ND) & DII \\
\hline SUNY at Albany (NY) & RII & University of Oklahoma, Norman Campus (OK) & RII \\
\hline SUNY at Buffalo (NY) & RII & University of Oregon (OR) & RII \\
\hline Temple University (PA) & $\mathrm{RI}$ & University of Pittsburgh (PA) & $\mathrm{RI}$ \\
\hline Texas A\&M University (TX) & RI & University of Rhode Island (RI) & RII \\
\hline Texas Tech University (TX) & RII & University of South Carolina at Columbia (SC) & RII \\
\hline University of Alaska at Fairbanks (AK) & Dll & University of South Dakota (SD) & DII \\
\hline University of Alabama - Birmingham (AL) & RI & University of South Florida (FL) & RII \\
\hline University of Arizona (AZ) & $\mathrm{RI}$ & University of Tennessee at Knoxville (TN) & $\mathrm{RI}$ \\
\hline University of Arkansas (AR) & RII & University of Texas at Austin (TX) & $\mathrm{RI}$ \\
\hline University of California-Berkeley (CA) & RI & University of Utah (UT) & RI \\
\hline University of California-Davis (CA) & RI & University of Vermont (VT) & RII \\
\hline University of California-Irvine (CA) & $\mathrm{RI}$ & University of Virginia (VA) & RI \\
\hline University of California-Los Angeles (CA) & RI & University of Washington - Seattle (WA) & RI \\
\hline University of California-Riverside (CA) & RII & University of Wisconsin-Madison (WI) & $\mathrm{RI}$ \\
\hline University of California-San Diego (CA) & $\mathrm{RI}$ & University of Wisconsin-Milwaukee (WI) & RII \\
\hline University of California-Santa Barbara (CA & RI & University of Wyoming (WY) & RII \\
\hline University of California-Santa Cruz (CA) & RII & Utah State University (UT) & RI \\
\hline University of Cincinnati $(\mathrm{OH})$ & RI & Virginia Commonwealth University (VA) & RI \\
\hline University of Colorado at Boulder (CO) & RI & Virginia Polytechnic Institute (VA) & RI \\
\hline University of Connecticut (CT) & $\mathrm{RI}$ & Washington State University (WA) & RII \\
\hline University of Delaware (DE) & RII & Wayne State University (MI) & $\mathrm{RI}$ \\
\hline University of Florida (FL) & RI & West Virginia University (WV) & RI \\
\hline
\end{tabular}

states in ()

Carnegie Classification descriptions can be found at http://chronicle.com/stats/carnegie 
Table 2

Proportion of First-Time Freshmen from Out-of-State (excluding foreign students) Flagship Public Research and Doctoral Institutions

\begin{tabular}{lcccccc}
\hline Year & $\begin{array}{c}\text { Unweighted } \\
\text { Average }\end{array}$ & $\begin{array}{c}\text { Standard } \\
\text { Deviation }\end{array}$ & $\begin{array}{c}\text { Weighted }^{b} \\
\text { Average }\end{array}$ & Median & Minimum & Maximum \\
\hline 1979 & 0.174 & 0.120 & 0.168 & 0.136 & 0.011 & 0.550 \\
1981 & 0.166 & 0.120 & 0.161 & 0.133 & 0.007 & 0.543 \\
1984 & 0.171 & 0.128 & 0.170 & 0.127 & 0.010 & 0.629 \\
1988 & 0.203 & 0.136 & 0.205 & 0.158 & 0.012 & 0.602 \\
1992 & 0.205 & 0.157 & 0.201 & 0.169 & 0.001 & 0.660 \\
1994 & 0.202 & 0.152 & 0.196 & 0.172 & 0.005 & 0.674 \\
1996 & 0.196 & 0.145 & 0.194 & 0.167 & 0.005 & 0.665 \\
1998 & 0.191 & 0.139 & 0.185 & 0.179 & 0.006 & 0.660 \\
\hline$\% \Delta$ & 9.4 & 15.7 & 10.3 & 31.2 & -47.8 & 19.9 \\
\hline
\end{tabular}

${ }^{a}$ Numbers of out-of-state freshmen imputed for the 8 California schools in 1984

${ }^{b}$ Weights are full-time equivalent first time freshmen enrollments

Source: NCES Higher Education General Information Surveys (HEGIS), Integrated Postsecondary Education Data System (IPEDS) via direct surveys and WebCASPAR 
Table 3

In-State and Out-of-State Tuition Levels (1996 dollars)

Flagship Public Research and Doctoral Institutions

\begin{tabular}{|c|c|c|c|c|c|c|c|c|c|c|}
\hline \multirow[b]{2}{*}{ Year } & \multicolumn{5}{|c|}{ In-State } & \multicolumn{5}{|c|}{ Out-of-State } \\
\hline & Average & Wtd. Avg. & Median & Minimum & Maximum & Average & Wtd. Avg. & Median & Minimum & Maximum \\
\hline \multirow[t]{2}{*}{1979} & & 1,582 & 1,509 & 676 & 3,435 & 4,250 & 4,246 & 4,097 & 2,068 & 8,182 \\
\hline & (520) & & & & & $(1,273)$ & & & & \\
\hline \multirow[t]{2}{*}{1981} & 1,633 & 1,667 & 1,569 & 638 & 3,799 & 4,431 & 4,460 & 4,105 & 1,844 & 8,402 \\
\hline & (615) & & & & & $(1,401)$ & & & & \\
\hline \multirow[t]{2}{*}{1984} & 1,943 & 2,006 & 1,861 & 557 & 5,126 & 5,203 & 5,334 & 5,047 & 1,755 & 9,799 \\
\hline & (756) & & & & & $(1,614)$ & & & & \\
\hline \multirow[t]{2}{*}{1988} & 2,266 & 2,320 & 2,100 & 1,018 & 4,840 & 6,282 & 6,454 & 6,059 & 3,238 & 13,393 \\
\hline & (859) & & & & & $(1,833)$ & & & & \\
\hline \multirow[t]{2}{*}{1992} & 2,833 & 2,887 & 2,656 & 1,315 & 6,724 & 8,055 & 8,243 & 7,604 & 4,139 & 16,103 \\
\hline & $(1,065)$ & & & & & $(2,551)$ & & & & \\
\hline \multirow[t]{2}{*}{1994} & 3,145 & 3,174 & 2,847 & 1,417 & 6,919 & 8,766 & 8,939 & 8,169 & 3,982 & 17,131 \\
\hline & $(1,189)$ & & & & & $(2,768)$ & & & & \\
\hline \multirow[t]{2}{*}{1996} & 3,348 & 3,397 & 3,102 & 1,568 & 7,726 & 9,459 & 9,689 & 9,030 & 5,100 & 17,916 \\
\hline & $(1,185)$ & & & & & $(2,659)$ & & & & \\
\hline \multirow[t]{2}{*}{1998} & 3,525 & 3,553 & 3,302 & 1,697 & 7,669 & 10,094 & 10,284 & 9,586 & 5,512 & 18,623 \\
\hline & $(1,181)$ & & & & & $(2,687)$ & & & & \\
\hline$\% \Delta$ & 127 & 125 & 119 & 151 & 123 & 137 & 142 & 134 & 167 & 128 \\
\hline CAGR & $4.2 \%$ & $4.1 \%$ & $4.0 \%$ & $4.7 \%$ & $4.1 \%$ & $4.4 \%$ & $4.5 \%$ & $4.3 \%$ & $5.0 \%$ & $4.2 \%$ \\
\hline
\end{tabular}

CAGR: "Compound Annual Growth Rate"

Source: NCES Higher Education General Information Surveys (HEGIS), Integrated Postsecondary Education Data System (IPEDS) via WebCASPAR 
Table 4

In-State, Out-of-State Tuition Differentials (1996 dollars)

Flagship Public Research and Doctoral Institutions

\begin{tabular}{l|c|c|c|c|c}
\hline Year & Mean & $\begin{array}{c}\text { Weighted } \\
\text { Average }\end{array}$ & Median & Minimum & Maximum \\
\hline 1979 & 2,698 & 2,664 & 2,537 & 1,138 & 5,028 \\
1981 & 2,798 & 2,793 & 2,517 & 1,077 & 5,321 \\
1984 & 3,260 & 3,328 & 3,150 & 1,198 & 6,526 \\
1988 & 4,016 & 4,133 & 3,878 & 1,469 & 8,968 \\
1992 & 5,222 & 5,357 & 4,855 & 1,878 & 10,891 \\
1994 & 5,620 & 5,765 & 5,471 & 1,770 & 11,439 \\
1996 & 6,110 & 6,292 & 6,060 & 2,400 & 12,206 \\
1998 & 6,569 & 6,731 & 6,471 & 2,537 & 12,695 \\
\hline$\% \Delta$ & 143 & 153 & 155 & 123 & 152 \\
CAGR & $4.5 \%$ & $4.7 \%$ & $4.8 \%$ & $4.1 \%$ & $4.7 \%$ \\
\hline
\end{tabular}

Weights are full-time equivalent first time freshmen enrollment

Source: NCES Higher Education General Information Surveys (HEGIS), Integrated

Postsecondary Education Data System (IPEDS) via direct surveys and WebCASPAR 
Table 5

Need Based Grant Aid to Instate Undergraduate Public Students per FTE Public Undergraduate in the State (1996 dollars)

Flagship Public Research and Doctoral Institutions

\begin{tabular}{lccccc}
\hline Year & $\begin{array}{c}\text { Unweighted } \\
\text { Average }\end{array}$ & $\begin{array}{c}\text { Standard } \\
\text { Deviation }\end{array}$ & Median & Minimum & Maximum \\
\hline 1979 & 67.5 & 78.4 & 34.9 & 5.4 & 415.9 \\
1981 & 77.2 & 89.9 & 45.2 & 4.5 & 410.9 \\
1984 & 93.2 & 127.0 & 51.3 & 11.0 & 663.4 \\
1988 & 117.0 & 134.2 & 60.9 & 10.3 & 594.8 \\
1992 & 128.6 & 140.4 & 89.2 & 9.0 & 644.0 \\
1994 & 139.1 & 162.4 & 92.0 & 10.8 & 881.1 \\
1996 & 183.5 & 196.6 & 125.8 & 10.7 & 949.1 \\
1998 & 284.7 & 322.0 & 180.2 & 6.8 & 1585.6 \\
\hline$\% \Delta$ & 321.6 & 310.8 & 416.8 & 25.6 & 281.2 \\
CAGR & $7.5 \%$ & $7.3 \%$ & $8.6 \%$ & $1.1 \%$ & $6.9 \%$ \\
\hline
\end{tabular}

Source: NASSGAP Annual Reports, HEGIS and IPEDS 
Table 6

State Appropriations per FTE Undergraduate (1996 dollars)

Flagship Public Research and Doctoral Institutions

\begin{tabular}{ccccccc}
\hline Year & $\begin{array}{c}\text { Unweighted } \\
\text { Average }\end{array}$ & $\begin{array}{c}\text { Weighted } \\
\text { Average }\end{array}$ & $\begin{array}{c}\text { Standard } \\
\text { Deviation }\end{array}$ & Median & Minimum & Maximum \\
\hline 1979 & 9,446 & 8,932 & 4,355 & 8,430 & 3,200 & 25,297 \\
1981 & 9,394 & 8,809 & 4,757 & 8,532 & 3,126 & 29,429 \\
1984 & 9,977 & 9,544 & 4,495 & 9,162 & 3,180 & 26,045 \\
1988 & 11,397 & 10,788 & 5,203 & 10,615 & 3,698 & 24,741 \\
1992 & 11,227 & 10,934 & 4,769 & 10,549 & 3,300 & 26,736 \\
1994 & 11,069 & 10,835 & 4,522 & 10,454 & 3,361 & 25,372 \\
1996 & 11,204 & 10,922 & 4,429 & 10,666 & 3,180 & 24,421 \\
1998 & 10,777 & 10,569 & 4,030 & 10,429 & 3,218 & 23,306 \\
2000 & 11,402 & 11,173 & 4,364 & 11,032 & 3,328 & 24,073 \\
\hline$\% \Delta$ & 20.7 & 25.1 & 0.2 & 30.9 & 4.0 & -4.8 \\
CAGR & $0.9 \%$ & $1.0 \%$ & $0.0 \%$ & $1.2 \%$ & $0.2 \%$ & $-0.2 \%$ \\
\hline
\end{tabular}

Source: HEGIS and IPEDS 


\section{Figure 2}

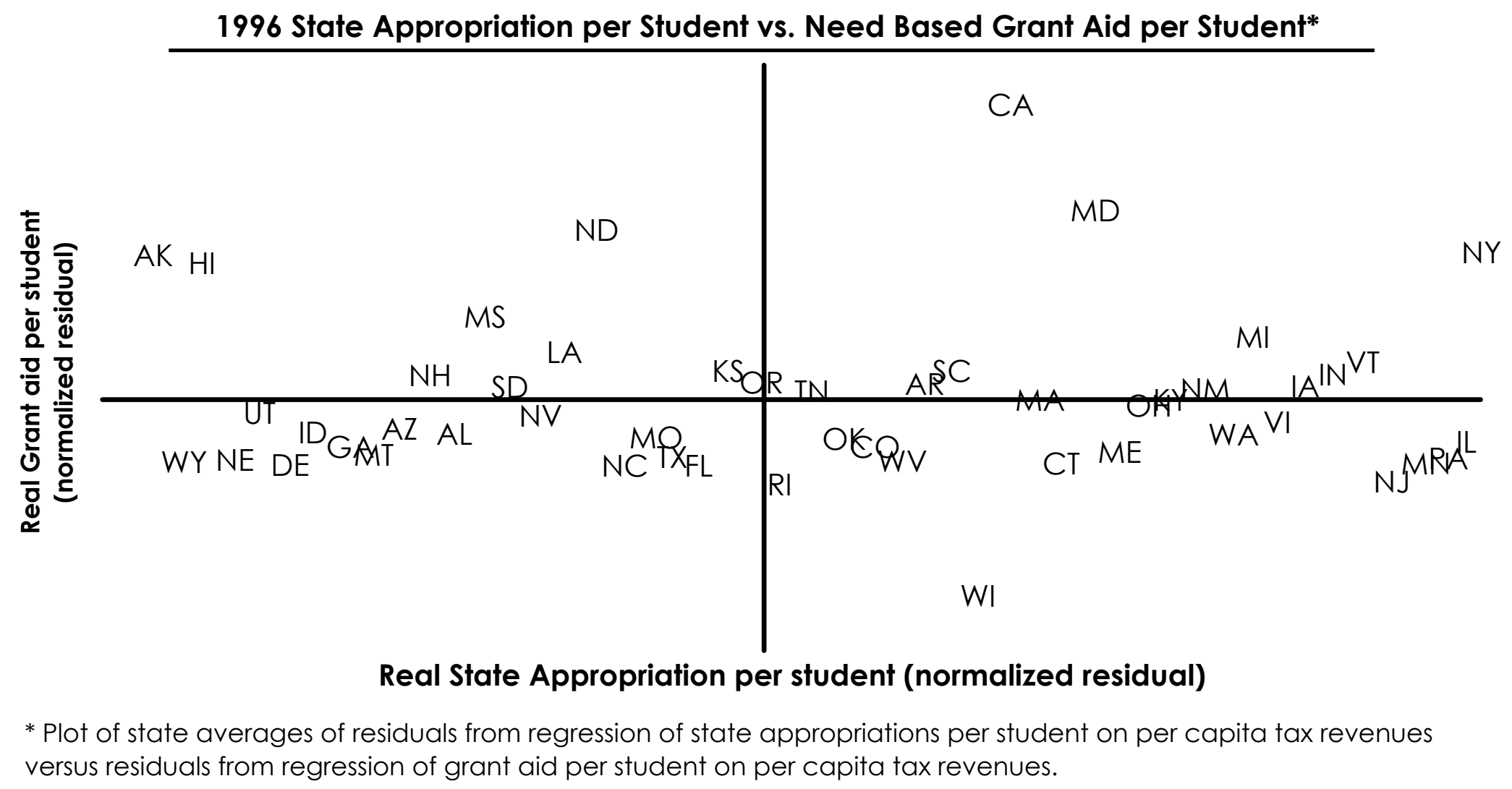


Table 7

Tuition Reciprocity Agreements

\begin{tabular}{|c|c|c|c|c|c|c|}
\hline 1 & II & III & IV & V & $\mathrm{VI}$ & VII \\
\hline Year & $\begin{array}{l}\text { \# schools } \\
\text { reporting } \\
\text { reciprocal } \\
\text { enrollments }\end{array}$ & $\begin{array}{l}\text { agreements, } \\
\text { but don't } \\
\text { report } \\
\text { enrollment }\end{array}$ & $\begin{array}{l}\text { Mean share of } \\
\text { undergrads } \\
\text { that are } \\
\text { reciprocal }\end{array}$ & $\begin{array}{l}\text { Max share of } \\
\text { undergrads } \\
\text { that are } \\
\text { reciprocal }\end{array}$ & $\begin{array}{l}\text { Mean share } \\
\text { of enrollment } \\
\text { that are } \\
\text { nonresidents* }\end{array}$ & $\begin{array}{c}\text { Mean share } \\
\text { nonresidents } \\
\text { that are } \\
\text { reciprocal }\end{array}$ \\
\hline 1979 & 3 & 36 & & & & \\
\hline 1981 & 4 & 35 & & & & \\
\hline 1984 & 10 & 29 & $3.6 \%$ & $16.6 \%$ & $21.5 \%$ & $16.7 \%$ \\
\hline 1988 & 15 & 24 & $3.1 \%$ & $22.4 \%$ & $23.8 \%$ & $13.0 \%$ \\
\hline 1992 & 20 & 19 & $7.6 \%$ & $30.1 \%$ & $24.2 \%$ & $31.4 \%$ \\
\hline 1994 & 24 & 15 & $6.7 \%$ & $30.1 \%$ & $25.4 \%$ & $26.4 \%$ \\
\hline 1996 & 28 & 11 & $5.5 \%$ & $28.6 \%$ & $23.9 \%$ & $23.0 \%$ \\
\hline
\end{tabular}

* for those schools that report reciprocal enrollment 
Table 8

Expected Impacts and Exclusion Restrictions in Estimated Equations

\begin{tabular}{|c|c|c|c|c|}
\hline \multirow[b]{2}{*}{ Variable } & \multicolumn{4}{|c|}{ Equation } \\
\hline & Grant Aid & $\begin{array}{l}\text { In-state } \\
\text { Tuition }\end{array}$ & $\begin{array}{c}\text { Out-State } \\
\text { Tuition }\end{array}$ & $\begin{array}{c}\text { Non- } \\
\text { resident } \\
\text { Share }\end{array}$ \\
\hline Log need based grant aid per public student (AID) & & $D+$ & & \\
\hline Log in-state tuition (TUITI) & $B+$ & & $S+$ & \\
\hline Log out-state tuition (TUITO) & & & & B? \\
\hline Log nonresident enrollment share (NON) & & & B? & \\
\hline Log state tax revenues per capita (TAX) & $\mathbf{S}+$ & & & \\
\hline Share of population aged 18-24 (AGE) & $\mathbf{S}=$ & $\mathbf{D}+$ & $\mathbf{D}+$ & $D+$ \\
\hline Share of population with incomes below Max Pell allowable (ELIG) & $\mathbf{D}+$ & D = & D - & D - \\
\hline Log maximum Pell grant award (PELL) & B - & $\mathbf{D}+$ & $\mathbf{D}+$ & $D+$ \\
\hline Percent cap on costs (CAP) & D - & $D+$ & $D+$ & $D+$ \\
\hline Post-1979 subsidized loan access (1979) & $\mathbf{D +}$ & D - & D - & D - \\
\hline Post-1992 subsidized loan access (1992) & $\mathbf{D}+$ & D - & D - & D - \\
\hline Log state appropriations per student (APP) & B - & B? & B? & B ? \\
\hline Log endowment per student (END) & B - & $\mathbf{B}+$ & $\mathbf{B}+$ & B? \\
\hline Ratio of fte grad to undergrad enrollments (GRAD) & D - & B? & B? & B? \\
\hline Share of fteftf in state in privates (PRIV) & B? & $\mathbf{S +}$ & & \\
\hline Share of fteftf in state in 2 years (TWO) & B? & S - & & \\
\hline Weak barron's rank (LOWB) & & D - & D - & D - \\
\hline Strong barron's rank (HIGHB) & & $D+$ & $\mathbf{D}+$ & $D+$ \\
\hline Weighted barrons's rank of privates in state (BPRIV) & $\mathbf{B}+$ & D - & & \\
\hline Weighted barrons's rank of publics in state (BPUB) & B? & & & \\
\hline Institution's share of quality public seats in the state (BSPUB) & & & $\mathrm{B}+$ & $D+$ \\
\hline Institution's share of qual. private seats in the state (BSPRIV) & & & $\mathbf{B}+$ & $\mathbf{D}+$ \\
\hline Share of quality seats in region that are private (SPRIV) & & & $D+$ & $D+$ \\
\hline Log seating capacity (SEAT) & $\mathbf{S +}$ & D - & B? & $\mathbf{S +}$ \\
\hline Log SAT (SAT) & & & & S - \\
\hline Log composite regional tuition (TUITR) & B - & $S+$ & $\mathrm{D}+$ & $D+$ \\
\hline Log share of fte undergrads in reciprocity agreements (RECIP) & & & & B? \\
\hline Log unemployment (UNEMP) & D? & D? & B? & B? \\
\hline Log number of governing boards (GOV) & S? & $\mathbf{S +}$ & $\mathbf{S +}$ & S? \\
\hline State merit-based aid programs (MERIT) & B - & $\mathbf{B}+$ & $\mathbf{S +}$ & S - \\
\hline
\end{tabular}

Endogenous variables 
Table 9 - Part A

State Need Based Grant Aid and Instate Tuition Equations

2SLS Results

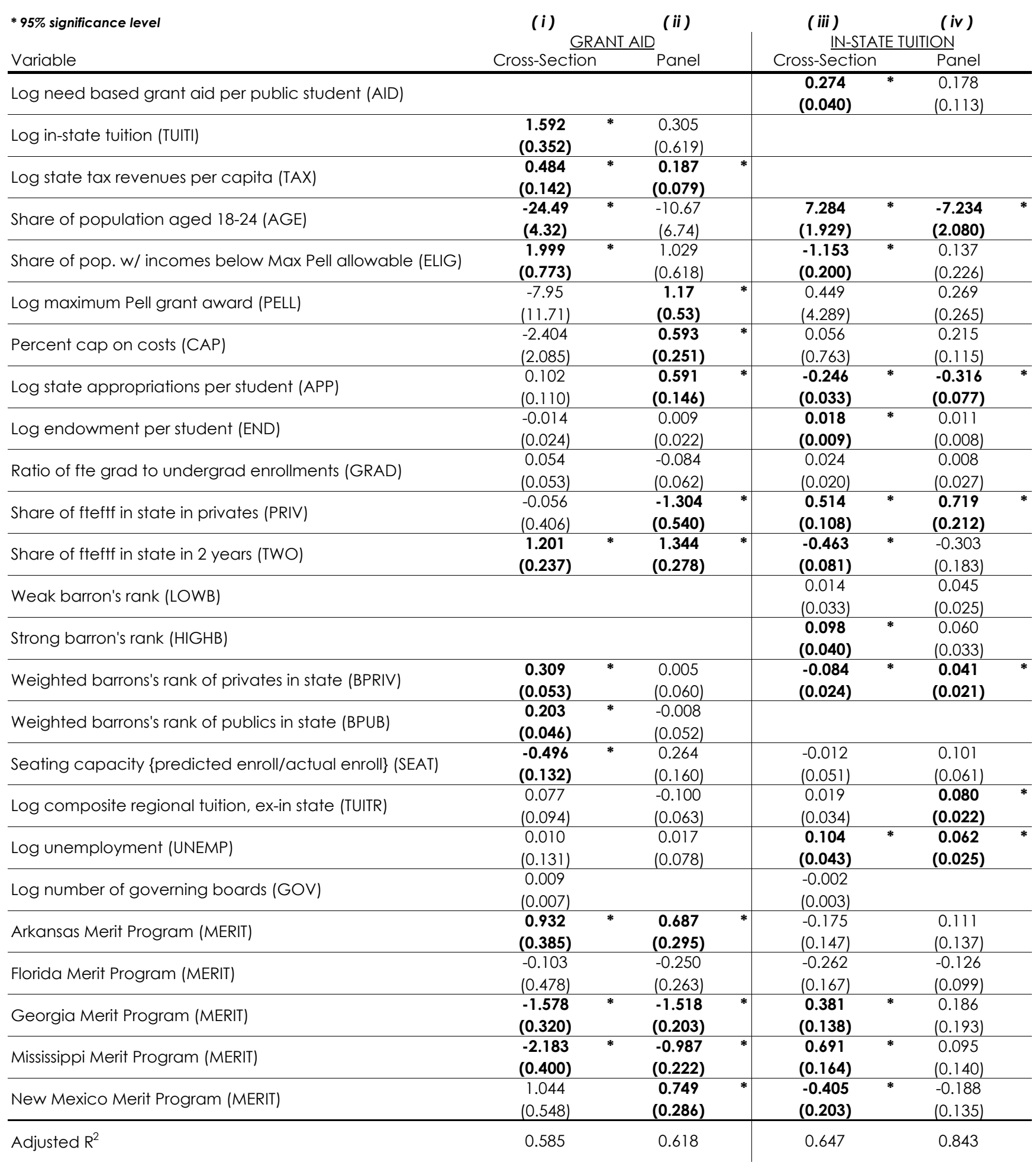


Table 9 - Part B

Out-of-State Tuition and Nonresident Enrollment Share Equations

2SLS Results

\begin{tabular}{|c|c|c|c|c|c|c|c|}
\hline \multirow{2}{*}{$\begin{array}{l}\text { *95\% significance level } \\
\text { Variable }\end{array}$} & \multicolumn{4}{|c|}{$\begin{array}{l}\text { (v) (vi) } \\
\text { OUT-STATE TUITION }\end{array}$} & \multicolumn{3}{|c|}{$\begin{array}{l}\text { (vii) (viii) } \\
\text { NON-RESIDENT SHARE }\end{array}$} \\
\hline & Cross-Section & & Panel & & Cross-Section & & Panel \\
\hline Log in-state tuition (TUITI) & $\begin{array}{c}0.488 \\
(0.055)\end{array}$ & * & $\begin{array}{c}0.902 \\
(0.060)\end{array}$ & $*$ & & & \\
\hline Log out-state tuition (TUITO) & & & & & $\begin{array}{l}-1.493 \\
(0.434)\end{array}$ & * & $\begin{array}{l}-0.264 \\
(0.357)\end{array}$ \\
\hline Log nonresident enrollment share (NON) & $\begin{array}{l}-0.028 \\
(0.022) \\
\end{array}$ & & $\begin{array}{l}-0.057 \\
(0.073) \\
\end{array}$ & & & & \\
\hline Log regional composite tuition (TUITR) & $\begin{array}{l}0.106 \\
(0.019)\end{array}$ & * & $\begin{array}{l}0.069 \\
(0.028)\end{array}$ & $*$ & $\begin{array}{c}0.343 \\
(0.125)\end{array}$ & * & $\begin{array}{c}0.371 \\
(0.069)\end{array}$ \\
\hline Share of population aged 18-24 (AGE) & $\begin{array}{l}-1.245 \\
(0.920)\end{array}$ & & $\begin{array}{c}1.130 \\
(1.047)\end{array}$ & & $\begin{array}{c}3.123 \\
(5.091)\end{array}$ & & $\begin{array}{c}4.570 \\
(3.909)\end{array}$ \\
\hline $\begin{array}{l}\text { Share of population with incomes below Max Pell } \\
\text { allowable (ELIG) }\end{array}$ & $\begin{array}{l}-0.691 \\
(0.135)\end{array}$ & * & $\begin{array}{c}0.053 \\
(0.153)\end{array}$ & & $\begin{array}{c}0.590 \\
(0.856)\end{array}$ & & $\begin{array}{l}-0.537 \\
(0.619)\end{array}$ \\
\hline Log maximum Pell grant award (PELL) & $\begin{array}{l}-0.087 \\
(2.521)\end{array}$ & & $\begin{array}{c}0.017 \\
(0.103)\end{array}$ & & $\begin{array}{c}-0.123 \\
(13.806)\end{array}$ & & $\begin{array}{l}-0.269 \\
(0.431)\end{array}$ \\
\hline Percent cap on costs (CAP) & $\begin{array}{l}-0.185 \\
(0.446)\end{array}$ & & $\begin{array}{l}-0.019 \\
(0.043)\end{array}$ & & $\begin{array}{c}0.161 \\
(2.447)\end{array}$ & & $\begin{array}{l}-0.023 \\
(0.210)\end{array}$ \\
\hline Log state appropriations per student (APP) & $\begin{array}{l}-0.049 \\
(0.032)\end{array}$ & & $\begin{array}{l}-0.002 \\
(0.031)\end{array}$ & & $\begin{array}{l}-1.305 \\
(0.123)\end{array}$ & * & $\begin{array}{l}-0.014 \\
(0.141)\end{array}$ \\
\hline Log endowment per student (END) & $\begin{array}{c}0.037 \\
(0.006)\end{array}$ & * & $\begin{array}{c}0.021 \\
(0.006)\end{array}$ & $*$ & $\begin{array}{c}0.211 \\
(0.033)\end{array}$ & * & $\begin{array}{c}0.034 \\
(0.024)\end{array}$ \\
\hline Ratio of fte grad to undergrad enrollments (GRAD) & $\begin{array}{c}-0.039 \\
(0.012)\end{array}$ & * & $\begin{array}{c}0.025 \\
(0.017) \\
\end{array}$ & & $\begin{array}{l}-0.079 \\
(0.064) \\
\end{array}$ & & $\begin{array}{l}-0.096 \\
(0.069) \\
\end{array}$ \\
\hline Poor Barrons's rank (LOWB) & $\begin{array}{l}-0.099 \\
(0.019)\end{array}$ & * & $\begin{array}{l}-0.002 \\
(0.017)\end{array}$ & & $\begin{array}{l}-0.406 \\
(0.116)\end{array}$ & * & $\begin{array}{c}0.018 \\
(0.071)\end{array}$ \\
\hline Strong Barrons's rank (HIGHB) & $\begin{array}{c}0.069 \\
(0.026)\end{array}$ & * & $\begin{array}{c}0.019 \\
(0.024)\end{array}$ & & $\begin{array}{l}-0.083 \\
(0.146)\end{array}$ & & $\begin{array}{c}0.107 \\
(0.095)\end{array}$ \\
\hline Institution's share of quality public seats in the state (BSPUB) & $\begin{array}{l}-0.026 \\
(0.032)\end{array}$ & & $\begin{array}{c}0.041 \\
(0.031)\end{array}$ & & $\begin{array}{c}1.061 \\
(0.132)\end{array}$ & * & $\begin{array}{c}0.286 \\
(0.110)\end{array}$ \\
\hline Institution's share of qual. private seats in the state (BSPRIV) & $\begin{array}{c}0.0008 \\
(0.0011)\end{array}$ & & $\begin{array}{l}-0.0006 \\
(0.0011)\end{array}$ & & $\begin{array}{c}0.016 \\
(0.006)\end{array}$ & * & $\begin{array}{c}0.000 \\
(0.004)\end{array}$ \\
\hline Share of quality seats in region that are private (SPRIV) & $\begin{array}{c}0.191 \\
(0.049)\end{array}$ & * & $\begin{array}{l}-0.137 \\
(0.059)\end{array}$ & * & $\begin{array}{c}0.716 \\
(0.293)\end{array}$ & * & $\begin{array}{l}-0.593 \\
(0.200)\end{array}$ \\
\hline Seating capacity \{predicted enroll/actual enroll\} (SEAT) & $\begin{array}{c}0.137 \\
(0.026)\end{array}$ & * & $\begin{array}{l}-0.017 \\
(0.040)\end{array}$ & & $\begin{array}{l}-0.112 \\
(0.120)\end{array}$ & & $\begin{array}{l}-0.285 \\
(0.151)\end{array}$ \\
\hline Log SAT (SAT) & & & & & $\begin{array}{l}-1.207 \\
(0.596)\end{array}$ & * & $\begin{array}{c}0.210 \\
(1.085)\end{array}$ \\
\hline $\begin{array}{l}\text { Log share of fte undergrads in reciprocity agreements } \\
\text { (RECIP) }\end{array}$ & & & & & $\begin{array}{l}-0.065 \\
(0.021)\end{array}$ & * & $\begin{array}{c}0.052 \\
(0.036)\end{array}$ \\
\hline Log number of governing boards (GOV) & $\begin{array}{l}-0.0034 \\
(0.0016)\end{array}$ & * & & & $\begin{array}{c}-0.021 \\
(0.009)\end{array}$ & * & \\
\hline Log unemployment (UNEMP) & $\begin{array}{c}0.007 \\
(0.025)\end{array}$ & & $\begin{array}{l}-0.078 \\
(0.020)\end{array}$ & ${ }^{*}$ & $\begin{array}{l}-0.333 \\
(0.132)\end{array}$ & * & $\begin{array}{l}-0.169 \\
(0.076)\end{array}$ \\
\hline Arkansas Merit Program (MERIT) & $\begin{array}{l}-0.142 \\
(0.084)\end{array}$ & & $\begin{array}{l}-0.071 \\
(0.079)\end{array}$ & & $\begin{array}{l}-0.110 \\
(0.462)\end{array}$ & & $\begin{array}{l}-0.428 \\
(0.307)\end{array}$ \\
\hline Florida Merit Program (MERIT) & $\begin{array}{l}-0.038 \\
(0.103)\end{array}$ & & $\begin{array}{c}0.093 \\
(0.107)\end{array}$ & & $\begin{array}{l}-1.339 \\
(0.544)\end{array}$ & * & $\begin{array}{l}-1.163 \\
(0.260)\end{array}$ \\
\hline Georgia Merit Program (MERIT) & $\begin{array}{l}-0.059 \\
(0.069)\end{array}$ & & $\begin{array}{c}0.047 \\
(0.060)\end{array}$ & & $\begin{array}{l}-0.142 \\
(0.386)\end{array}$ & & $\begin{array}{l}-0.441 \\
(0.219)\end{array}$ \\
\hline Mississippi Merit Program (MERIT) & $\begin{array}{l}-0.300 \\
(0.085)\end{array}$ & * & $\begin{array}{c}0.045 \\
(0.059)\end{array}$ & & $\begin{array}{c}0.061 \\
(0.482)\end{array}$ & & $\begin{array}{c}0.188 \\
(0.241)\end{array}$ \\
\hline New Mexico Merit Program (MERIT) & $\begin{array}{c}0.118 \\
(0.118) \\
\end{array}$ & & $\begin{array}{c}0.037 \\
(0.077) \\
\end{array}$ & & $\begin{array}{c}0.305 \\
(0.644) \\
\end{array}$ & & $\begin{array}{c}0.176 \\
(0.316) \\
\end{array}$ \\
\hline Adjusted $\mathrm{R}^{2}$ & 0.865 & & 0.933 & & 0.374 & & 0.203 \\
\hline
\end{tabular}


Table 10

Effect of Selected Policy Changes on Outcomes

Fixed Effects Instrumental Variables Results

Evaluated at 1998 level of appropriate variable

Selected Policy Change

Grant Aid Instate Tuition Out-of-State Tuition Nonresident Share*

Increase state grant aid per fte undergrad in the state by

$\$ 100$ per student

$\$ 205$

Increase real in-state tuition by $\$ 1,000$

$\$ 27$

$\$ 2,584$

Increase real out-of-state tuition by $\$ 1,000$

Increase nonresident enrollment share by 10 perc. pts

$-\$ 299$

Increase state tax revenues per capita by $\$ 1,000$

$\$ 11$

Increase maximum real Pell Grant award by $\$ 100$

$\$ 12$

$\$ 32$

$\$ 6$

$-0.26$

Increase real state appropriations per student by $\$ 1,000$

$\$ 17$

$-\$ 104$

Increase real endowment per student by $\$ 1,000$

$\$ 0$

$\$ 2$

$\$ 11$

0.05

Increase ratio of grad students to first time frosh by 10 pts

$-\$ 3$

$\$ 3$

$\$ 25$

Having lower than average Barron's ranking**

$\$ 160$

$-\$ 22$

$-0.15$

Having higher than average Barron's ranking**

$\$ 146$

$\$ 196$

1.07

$\$ 9$

$\$ 41$

$\$ 48$

Having higher SAT scores by 100 points in your state

Increasing the share of std. reciprocal by 10 perc. pts

Average 1998 Value of Dependent Variable

$\$ 307$

$\$ 3,525$

$\$ 10,094$

$19.1 \%$

\section{Items in bold are significant at $95 \%$ level}

* Represents percentage point changes, for example -2.0 would indicate nonresident share falls from $x \%$ to ( $x$-2)\%

** For enrollment equation, numbers indicate percentage point change in share due to being in this category relative to average

*** Table reports marginal effects evaluated at mean 


\section{Appendix Table 1 \\ Sources and Definitions of Variables}

Variable

1979

1992

AGE

AID

APP

BPRIV

BPUB

BSPRIV

BSPUB
Definition/Explanation *

Dummy for years subsequent to repeal of Middle Income Student Assistant Act in 1979

which reinstated "needs" test for eligibility for subsidized federal loans

Dummy for years subsequent to 1992 when the $5.64 \%$ of home equity that was taxable in the expected family contribution (EFC) calculation was removed from taxable assets

Share of population in a state between age $18 \& 24$

Logarithm of need based state grant aid to instate undergraduate students attending institutions in their own state per full-time equivalent four year undergraduate in the state. Includes federal matching LEAP/SSIG monies.

Logarithm of state government appropriations in 000's per full-time equivalent undergraduate at the institution

Undergraduate enrollment weighted average Barron's ranking of all rated four-year private institutions in the state.

Undergraduate enrollment weighted average Barron's ranking of all rated four-year public institutions in the state.

Institution's undergraduate enrollment divided by the total undergraduate enrollment of all equally or more highly rated private (Barron's) institutions in the state.

Institution's undergraduate enrollment divided by the total undergraduate enrollment of all equally or more highly rated public (Barron's) institutions in the state (including the institution of observation). 
CAP

ELIG

END

GOV

GRAD

HIGHB

LOWB

_MERIT

NON

PELL

PRIV
Maximum percentage of college costs covered by Pell Grants. Initially $50 \%$ of costs, raised to $60 \%$ in 1986 and eliminated in 1992.

Share of state's households with incomes below the maximum allowable to be eligible to received federal grant aid. Maximum income eligibility estimated from EFC calculation.

Logarithm of institutional endowment in 000's per full-time equivalent undergraduate at the institution.

Number of governing boards in the state.

Ratio of full-time equivalent graduate students to full-time equivalent undergraduate institutions at the institution.

Dummy variable equal to one if Barron's ranking is "Highly Competetive" or "Most Competetive."

Dummy variable equal to one if Barron's ranking is "Not Competetive" or "Less Competetive."

Dummy variable equal to one if state had a merit aid program in that year.

Logarithm of the share of first-time freshmen that are nonresident, non-foreign students. In nonresident share equation, we use the log-odds ratio. That is the share divided by one minus the share.

Logarithm of the maximum available Pell Grant award. 
RECIP

SAT

SEAT

SPRIV

TAX

TUITI

TUITO

TUITR (EQUN 1\&2)

TUITR (EQUN 3\&4)

TWO

UNEMP
Logarithm of the share of full-time equivalent undergraduates enrolled under tuition reciprocity programs.

Average SAT score in the state (includes public and private high school students).

Maximum number of full-time equivalent first-time freshmen enrollment in the state historically at public schools of equal or greater Barron's rank divided by the current number of high school graduates in the state.

In the census region, the share of full-time equivalent first time freshmen in schools that are of equal or greater Barron's rank that are enrolled in private schools.

Logarithm of total state tax revenues received per population in the state, excludes federal receipts, in 000's.

Logarithm of in-state tuition charged.

Logarithm of out-of-state tuition charged.

Logarithm of the enrollment weighted average of public out-of-state (for schools outside my state), public instate (for schools in my state, excluding my school) and private tuition in the census region.

Logarithm of the enrollment weighted average of public in-state, public out-of-state and private tuition in the census region, including schools in the state of observation.

Share of public full-time equivalent first-time freshmen enrollment in the state that are in two-year colleges.

Logarithm of the state average unemployment rate.

* All data in real values using 1996 calendar year GDP implicit price deflator. 


\section{Data Sources}

1. United States Department of Education web-site

2. Michael Mumper, Removing College Price Barriers, SUNY Press, 1996.

3. U.S. Bureau of the Census, Population Estimates Program - Age distribution data on web-site.

4. National Association of State Scholarship and Grant Programs, Annual Survey Reports.

5. Integrated Postsecondary Education Data System Surveys via WebCASPAR. See http://caspar.nsf.gov or www.nces.ed.gov/ipeds.

6. Barron's Profiles of American Colleges, 1979-1996.

7. American Councilon Education Center for Policy Analyisis, 2000 Status Report on the Pell Grant Program .

8. Current Population Surveys, Estimates of Income of Households by State 1979-1996.

9. Education Commission of the States.

10. Older resident enrollment data from Higher Education General Information Surveys not available on WebCASPAR was retrieved through original "Fall Residence and Migration Surveys."

11. Cornell Higher Education Research Institute (CHERI) Survey of Tuition Reciprocity Programs at Public Research and Doctoral Institutions, Summer 2001. Available on CHERI website at www.ilr.cornell.edu/cheri.

12. U.S. Department of Education, National Center for Education Statistics, Digest of Education Statistics .

13. U.S. Bureau of the Census, Census of Governments via the Statistical Abstract of the United States.

14. U.S. Department of Labor, Bureau of Labor Statistics. Employment and Earnings. 
Appendix Table 2

Summary Statistics

Average Values of Independent Variables*

\begin{tabular}{|c|c|c|c|c|c|c|c|}
\hline Variable & 1979 & 1981 & 1988 & 1992 & 1994 & 1996 & 1998 \\
\hline \# grad students / \# first time freshmen & 1.20 & 1.24 & 1.27 & 1.59 & 1.58 & 1.49 & 1.10 \\
\hline \# schools strong Barrons rank & 2 & 3 & 5 & 13 & 11 & 11 & 11 \\
\hline \# schools weak Barrons rank & 17 & 15 & 16 & 13 & 7 & 11 & 11 \\
\hline Average SAT scores of HS grads & 936 & 939 & 1,042 & 966 & 1,043 & 1,057 & 1,062 \\
\hline Composite regional tuition & 2,932 & 3,086 & 5,567 & 6,090 & 6,332 & 6,672 & 7,059 \\
\hline Composite regional tuition, ex-instate & 4,217 & 4,439 & 8,005 & 8,721 & 9,047 & 9,541 & 10,002 \\
\hline Endowment per student & 957 & 1,401 & 4,466 & 7,726 & 9,809 & 13,977 & 19,337 \\
\hline Instn's share of state's quality private seats & $251.0 \%$ & $299.3 \%$ & $262.0 \%$ & $267.7 \%$ & $273.9 \%$ & $191.6 \%$ & $191.6 \%$ \\
\hline Instn's share of state's quality public seats & $47.9 \%$ & $47.5 \%$ & $52.9 \%$ & $50.8 \%$ & $51.1 \%$ & $49.9 \%$ & $49.9 \%$ \\
\hline Pell grant award (real) & 3,416 & 2,663 & 2,734 & 2,617 & 2,392 & 2,470 & 2,917 \\
\hline Per capita real state tax revenues & 2,279 & 1,865 & 3,070 & 2,535 & 2,669 & 4,720 & 5,185 \\
\hline Seating capacity (predicted/actual) & 1.34 & 1.31 & 0.99 & 0.82 & 0.82 & 0.81 & 0.86 \\
\hline Share of fteftf in state in privates & $30.3 \%$ & $30.7 \%$ & $30.0 \%$ & $31.1 \%$ & $30.7 \%$ & $30.2 \%$ & $23.3 \%$ \\
\hline Share of fteftf in state in two-years & $45.7 \%$ & $47.3 \%$ & $44.0 \%$ & $46.0 \%$ & $44.9 \%$ & $44.2 \%$ & $41.9 \%$ \\
\hline Share of population aged 18-24 & $13.5 \%$ & $13.3 \%$ & $11.1 \%$ & $10.2 \%$ & $9.9 \%$ & $9.6 \%$ & $9.7 \%$ \\
\hline Share of population with incomes below Pell & $63.9 \%$ & $57.5 \%$ & $53.5 \%$ & $49.3 \%$ & $45.0 \%$ & $44.9 \%$ & $49.8 \%$ \\
\hline Share of quality regional seats - private & $37.8 \%$ & $37.3 \%$ & $39.4 \%$ & $40.9 \%$ & $40.0 \%$ & $39.5 \%$ & $39.5 \%$ \\
\hline Unemployment rate & 5.78 & 6.91 & 6.43 & 6.51 & 6.36 & 5.38 & 4.80 \\
\hline Weighted rank of privates in state & 2.56 & 2.64 & 2.90 & 2.74 & 2.98 & 2.98 & 2.98 \\
\hline Weighted rank of publics in state & 2.38 & 2.39 & 2.60 & 2.60 & 2.66 & 2.67 & 2.67 \\
\hline
\end{tabular}

* for those variables not in earlier tables 